\title{
A PROPERTY THEORY OF CORPORATE LAW
}

\author{
Robert Anderson IV*
}

The dominant view of the corporation in legal scholarship is contractarian, one that sees the corporation as a "nexus of contracts" among the various suppliers of inputs to the business, such as investors, creditors, and employees. According to this view, the holders of common stock-those who are traditionally the primary focus of corporate law-are not the owners of the corporation, but just one of many contractual claimants. As a result, the corporation is a free-floating nexus of contracts with no property interests in the corporation itself or its assets. Thus, corporate law is seen as essentially a specialized branch of contract law.

The contractarian metaphor has largely persuaded the academy and much of the corporate law bench, evidenced by the regularity in which Delaware courts interpret charter documents as "contracts." Courts and commentators alike regard corporate law as essentially a set of "off-the-rack" contractual default rules provided by the state. Yet the contractarian metaphor has struggled to account for some of the most fundamental features of corporate law. For example, the nexus of contracts view fails to adequately explain why fiduciary duties attach uniquely to shareholders and not to other contractual claimants on the corporation. Equally important, the nexus of contracts approach also fails to account for the many in rem

* Professor of Law, Pepperdine University Caruso School of Law. I would like to thank Stephen Bainbridge, Jordan Barry, Vincent Buccola, Lynne Dallas, Danielle D’Onfro, Joan MacLeod Heminway, Ann Lipton, Dorothy Lund, Paul Miller, George Mocsary, Greg Shill, Mike Simkovic, and Julian Velasco, for their helpful comments. I would especially like to thank the participants at presentations of this paper at the National Business Law Scholars Conference and the works in progress workshop series of the Murphy Institute at Tulane Law School for their helpful comments. 
features of the corporation that contract law could not easily replicate. There is a piece missing in the contractarian account of the corporation.

This Article argues that property law provides the missing piece of the contractarian puzzle in demarcating the boundaries of corporate law and explaining the distinctive features of $i t$. In the property theory, the corporation is an ownership structure-a device for turning a messy set of in personam claims into an orderly package of in rem property rights, called "shares." The in rem structure depersonalizes these rights, allowing them to be divided and transferred without contractual assent and without entangling the personal attributes of the holder. The key to the proprietary nature of this ownership interest is the residual control-voting rights - that solidify the status of common stock as a property interest rather than a contractual interest.

The property theory's assertion that claims on the corporation are a mix of property and contract rights provides traction in otherwise slippery areas of corporate law. If there is a line to be drawn between contract and property, this dividing line identifies the boundaries of distinctively corporate law from contract law. Accordingly, the rationale for shareholder-only fiduciary duties is not primarily that shareholders are the residual claimants in the economic sense, but that they have a residual control right constituting an ownership interest unique among corporate claimants. The property theory of corporate law best explains many features of corporate law and clarifies otherwise murky line drawing exercises in defining the scope of fiduciary duties.

I. Introduction 3

II. The Contractual Theory and Its Limitations

A. The Contractual Theory of the Firm....

B. The Contractual Theory of the Corporation

C. The Theory of the Firm versus the Legal Backdrop

1. Common Stock and Property Theory

2. Problems with Common Stock as Contract. 
III. Building a Property Theory of Corporate Law 45

A. The Corporation as an Ownership Structure .........46

B. Property Theory, the Right to Exclude, and Corporate Law 48

C. The Property-Contract Borderline: Replicability of

Corporate Law 54

1. The Breadth of Property Rights ......................554

2. The Depth of Property Rights .........................62

3. The Boundary Question in Corporate Law .......64

4. The New Literature on Property in the Corporation

D. The Property-Fiduciary Connection

IV. Property Versus Contract Residual Claims as

Explanations of Fiduciary Duties.............................70

A. Revising Residual Claimant Analysis....................71

B. How the Theory of the Firm Became a Theory of Corporate Law ..................................................... 76

C. Implications for Theory of the Firm....................... 78

V. The Implications for Corporate Law..............................8 82

A. Contractual Rights in the Charter.........................83

B. Fiduciary Duties to Holders of Preferred Stock, Warrants, and Convertible Securities .................86

C. Dual-Class Stock and Other Non-Standard Capital

Structures ....................................................99

D. Fiduciary Duties in the Zone of Insolvency ............94

E. Social Purposes of the Corporation .......................98

VI. Conclusion........................................................ 102

\section{INTRODUCTION}

The dominant view of the corporation in legal scholarship is contractarian, one that sees the corporation as a "nexus of contracts" among factors of production. ${ }^{1}$ Arising from the law

1 See, e.g., Stephen M. Bainbridge, The Board of Directors as Nexus of Contracts, 88 IowA L. REV. 1, 9 (2002) ("The dominant model of the corporation in legal scholarship is the so-called nexus of contracts theory."); Stephen M. Bainbridge, Director Primacy: The Means and Ends of Corporate Governance, 97 Nw. U. L. REV. 547, 550 (2003) (describing the contractarian theory as the "prevailing" theory of the firm and stating that the "standard 
and economics literature, this perspective views employees, creditors, equity investors, and even customers as the various "actors" who form a "set of implicit and explicit contracts" that collectively make up the corporation. ${ }^{2}$ This perspective emphasizes that the firm is largely a collection of voluntary arrangements against the backdrop of default rules-in other words, contracts-rather than a governmental concession with mandatory rules. ${ }^{3}$ Because the corporation itself is a set of contracts, the law governing the internal affairs of corporations-corporate law-is itself merely a specialized branch of contract law. In other words, the corporation is "just contracts."

Although the contractarian perspective originated as a gloss on the theory of the firm as an economic entity, ${ }^{4}$ it has profoundly influenced scholarly and judicial thinking on the corporation as a legal entity. Whereas corporate lawyers traditionally view corporate law as governing the "internal

contractarian account treats the firm as a nexus of contracts"); Margaret M. Blair \& Lynn A. Stout, A Team Production Theory of Corporate Law, 85 VA. L. REV. 247, 287 (1999) ("During the past two decades, corporate scholarship has been dominated by a 'contractarian' or 'law and economics' approach.”); Melvin A. Eisenberg, The Conception That the Corporation is a Nexus of Contracts and the Dual Nature of the Firm, 24 J. CoRP. L. 819, 819 (1999) (noting that since Jensen and Meckling first formulated the nexus of contracts theory of the corporation, the approach "has dominated the law-andeconomics literature in corporate law"); Thomas W. Joo, Contract, Property, and the Role of Metaphor in Corporations Law, 35 U.C. DAVIS L. REV. 779, 780 (2002) (stating that the nexus of contracts model "dominates corporations law scholarship" and has become a "near-orthodoxy").

2 Frank H. Easterbrook \& Daniel R. Fischel, The Economic StrucTURE OF CORPORATE LAW 12 (1991). Easterbrook and Fischel even put tort claimants into this category. See id.

3 This assertion, too, is controversial. See, e.g., William W. Bratton, Jr., The "Nexus of Contracts" Corporation: A Critical Appraisal, 74 CoRnELL L. REV. 407, 438-46 (1989) (arguing that the nexus of contracts approach fails to appreciate the "sovereign presence" of the state, including its mandatory rules, in the institution of the corporation); Grant M. Hayden \& Matthew T. Bodie, The Uncorporation and the Unraveling of "Nexus of Contracts" Theory, 109 MicH. L. REV. 1127, 1128-29 (2011) (arguing that "state corporate law, rather than contractual decisions, frames the structure of the modern corporation").

4 See infra Section II.A. 
affairs" among shareholder owners and fiduciary managers, ${ }^{5}$ the contractarian theory views these relationships as contracts, much like other contracts the corporation enters into. ${ }^{6}$ In this view, the traditional idea of shareholders as "owners" of the corporation yields to one in which shareholders are contractual counterparties-suppliers of capital, and bearers of residual risk. ${ }^{7}$ The contractual paradigm leads most scholars to deny a meaningful role for ownership within the corporation at all. ${ }^{8}$ In this view, the shareholders are just another contractual claimant on the corporation-in the words of Yale Law School Professor Jonathan Macey and former Chief Justice of the Delaware Supreme Court Leo Strine, they are "not so special."9

The literal application of a purely contractual perspective to corporate law doctrine is a revolutionary idea, yet one with profoundly reactionary implications. The revolutionary aspect is that, contrary to black letter corporate law doctrine, the contractarian stance generates blurry or even nonexistent boundaries of the corporation, implying that there is no "inside" or "outside" of corporate law. When all of the claims on the corporation are contract claims, there are no clear boundaries of

5 See generally Deborah A. DeMott, Perspectives on Choice of Law for Corporate Internal Affairs, 48 LAW \& CONTEMP. PROBS. 161, 161 (1985) ("To many corporate lawyers, the 'internal affairs' doctrine - the notion that only one state, almost always the site of incorporation, should be authorized to regulate the relationships among a corporation and its officers, directors, and shareholders-is irresistible if not logically inevitable.").

6 See infra note 8 and accompanying text.

7 See Barry D. Baysinger \& Henry N. Butler, Race for the Bottom $v$. Climb to the Top: The ALI Project and Uniformity in Corporate Law, $10 \mathrm{~J}$. CORP. L. 431, 433 n.9 (1985) ("The modern contractural theory of the firm, however, suggests that it is meaningless to think of shareholders as 'owners' of the firm; they are properly viewed as risk bearers who supply the firm with one form of capital.").

8 See Julian Velasco, Shareholder Ownership and Primacy, 2010 U. ILL. L. REV. 897, 899 (2010) ("Today, however, there seems to be substantial agreement among legal scholars and others in the academy that shareholders do not own corporations."). Velasco disagrees with this view and sets forth arguments for a shareholder ownership theory of the corporation. See id. at 901 .

9 Jonathan Macey \& Leo E. Strine, Jr., Citizens United as Bad Corporate Law, 2019 WIS. L. REV. 451, 483 (2019). 
the firm; ${ }^{10}$ indeed, the theory arguably implies there's no such thing as a firm. ${ }^{11}$ This lack of an "inside" or "outside" stands in contrast to standard teaching on corporate law, which defines corporate law by reference to the "internal affairs" doctrine, the law applicable to the relations among those "inside" the corporation-the officers, directors, and shareholders. ${ }^{12}$ Indeed, the absence of an inside or outside arguably implies that there is no separate law of corporations or other business organizations-there are just contracts, albeit within a specialized context.

The reactionary implications of the contractarian perspective stem from the fact that if corporations are just contracts, there is not much for corporate law to do other than interpret, validate, and occasionally invalidate contracts, subject to the rules of contract law. This is because the contractarian perspective offers little guidance for clarifying the corporation's relationship with its traditional contractual claimants (employees, customers, suppliers, etc.), as those relationships have always been viewed as contractual and subject to the principles of contract law. What is new when the corporation is a nexus of contracts is that the shareholders should be viewed as contract claimants as well, with rights arising from

10 See, e.g., D. Gordon Smith, The Critical Resource Theory of Fiduciary Duty, 55 VAND. L. REV. 1399, 1432 (2002). Indeed, Jensen and Meckling explicitly take this position, arguing:

[I]t makes little or no sense to try to distinguish those things which are "inside" the firm . . . from those things that are "outside" of it. There is in a very real sense only a multitude of complex relationships (i.e., contracts) between the legal fiction (the firm) and the owners of labor, material and capital inputs and the consumers of output.

Michael C. Jensen \& William H. Meckling, Theory of the Firm: Managerial Behavior, Agency Costs and Ownership Structure, 3 J. Fin. Econ. 305, 311 (1976).

11 Eisenberg, supra note 1, at 832. Indeed, Gulati, Klein and Zolt take this additional step and articulate a model in which there are no firms, only "connected contracts." See G. Mitu Gulati et al., Connected Contracts, 47 UCLA L. REV. 887, 894 (2000).

12 See, e.g., Ann M. Lipton, Manufactured Consent: The Problem of Arbitration Clauses in Corporate Charters and Bylaws, 104 GEO. L.J. 583, 597 (2016). 
contract law. As a result, unless the contractual view of shareholders provides something new, the theory provides little traction beyond the rules of ordinary contract law to answer theoretical and doctrinal questions in corporate law.

The upshot is that the contractarian metaphor falls apart at the only place it does any work-in characterizing the relationship of the shareholders to the corporation. That is, it fails to explain even the most fundamental and important aspects of shareholders' relationship to the corporation, such as the source and scope of the fiduciary duties owed to them. ${ }^{13}$ Likewise, the contractarian view struggles to provide an account for the mandatory rules of corporate law ${ }^{14}$ such as, especially relevant for the purposes of this Article, the fiduciary concept. ${ }^{15}$ As a result, instead of providing new leverage on corporate legal problems, the contract metaphor is in large part simply a justification of whatever status quo "contractual" arrangements currently exist. ${ }^{16}$

The problems with the contractarian account of the shareholder relationship are compounded by the fact that the rules of corporate shareholder "contracts" bear little resemblance to those of regular contracts. ${ }^{17}$ As a result, even if the corporation is viewed as a mere nexus of contracts, the issue of identifying when contracts are within the internal affairs of the corporation (and therefore subject to special rules) persists. The contractarian account does not supply an answer to this linedrawing question, and as a result the nexus of contracts model fails to identify the boundaries of corporate law. Thus, although the nexus of contracts theory provides a useful foundation in explicating the economic theory of the firm, it either contradicts or fails to explain most of the important features of corporate law. The model therefore provides little new

13 See infra Section II.B.

14 See, e.g., Marc T. Moore, Corporate Governance In the Shadow OF THE STATE 4-6 (2013) (describing weaknesses of the contractarian account of mandatory rules in corporate law).

15 See id. at 219-23 (describing the fiduciary principle as a "gap-filling" rule).

16 See Hayden \& Bodie, supra note 3, at 1127.

17 See infra Section II.C.2. 
content for corporate law, straining even to explain the most basic existing features of the law.

This Article develops an explicitly legal theory of the corporation based upon property law, not contract law-a "property theory of corporate law." This Article augments the contractual theory of the firm by identifying the proprietary features that demarcate certain distinctively corporate law concepts from its other contractual features. The property theory argues that there are legal boundaries of the corporation, and that those boundaries largely follow the contract-property divide. The corporation is a nexus of contractual and proprietary interests, and the distinctive aspects of default and mandatory corporate law-fiduciary duty, voting, limited liability, perpetual existence, transferable shares-concern the proprietary portion of the corporation. In the property theory, the relevant residual claims on the corporation are the voting rights in the firm protected by default rules and fiduciary duties. Other interests in the firm, those of creditors, employees, suppliers, customers, and even most preferred stock rights, are contractual and protected by explicit terms and the duty of good faith.

The property theory of corporate law does not imply that all claims traditionally thought of as "corporate law" arise from property rather than contract. Shareholders, like other stakeholders, can contract with the firm and with other constituents, and these claims are like any other contract with the corporation. Rather, the property interests in the corporation are the residual governance rights that arise in the common stock directly from the relevant corporation statute-especially (but not uniquely) the plenary and residual voting rights. As a result, the contractual aspects of shareholders' claims on the corporation are those that go beyond the default rules of the corporation statute. Notably, many of the contract rights of preferred shareholders fall in this category, because preferred stock, by its nature, contains rights granted by the corporation's charter, not by the default rules of corporate law. ${ }^{18}$ But the core principles of corporate law that derive

18 See, e.g., In re Sunstates Corp. S'holder Litig., 788 A.2d 530, 533 (Del. Ch. 2001) ("Thus, the law recognizes that the existence and extent of 
either from the default or mandatory rules of corporations' statutes are more properly regarded as property rights.

This Article builds up the property theory of corporate law by applying a Coasean approach to the legal structure of the firm. ${ }^{19}$ Whereas Coase asked why transactions are organized for economic purposes in firms (fiat or hierarchy) rather than in markets (arm's length contracting), this Article asks why transactions are organized for legal purposes in corporations. Why are there corporations with shares and shareholders, as opposed to direct ownership of business assets with contracts among the owners? As will be shown, the traditional contractarian answer-emphasizing the residual risk bearing function of corporate shareholders-falls short, as risk allocation could be accomplished using other legal structures. The features of the corporation that cannot be replicated by contract law-the "in rem-ification" of the business relationships of the company-are those that constitute the core of corporate law. This is the extension and generalization of a series of articles recognizing the in rem or property elements of various aspects of organizational law. ${ }^{20}$

This Article proceeds in Part II by laying out the theory of the firm as the background of the contractarian perspective and its influence on the legal theory of the corporation. Part I then explains the difficulty of meshing a contractual theory with existing legal concepts in corporate law. Part I concludes by introducing the emerging property views that have challenged the pure nexus of contracts perspective.

Part III is the analytical core of the Article. It opens with the hypothesis that the corporation actually is more than a set contracts (and more than a mere adaptation of property law). Instead, the corporation is an ownership structure, a technology for bundling various property and non-property relationships, stripping them of cumbersome in personam features and packaging them into standardized units of easily divisible

rights of preferred stock must be determined by reference to the certificate of incorporation, those rights being essentially contractual in nature.").

19 See R.H. Coase, The Nature of the Firm, 4 Economica 386, 390 (1937).

$$
20 \text { See infra Section II.C.1. }
$$


and transferable property (shares). This perspective views the corporation as a way of owning business assets that converts messy in personam contract rights into tidy in rem property rights encapsulated in shares that are easily transferable.

Part III continues by deploying property theory to show that shareholders do hold property interests in the corporation. Central to this argument is that property theory emphasizes the "right to exclude" as a central (or arguably the defining) feature of property. The voting shareholders, as those who have the ability to elect and remove directors, are the unique holders of what this Article terms "a non-excludable right to exclude." This interest in the corporation, held solely by voting shareholders, is the claim on the corporation rightly conceived as an ownership interest. The boundaries of ownership are the boundaries of corporate law, meaning that the core of corporate law is better thought of as a subspecies of property law than of contract law. But the Part makes it clear that this is a thin form of property; it relates only to the default (and largely mandatory) features of the corporate organization. The Part continues by sketching the borderline between property and contract rights by asking what unique functions the legal institution of the corporation serves within a property conception of the law.

Part IV addresses how the property theory relates to the "residual claimant" analysis that pervades the law and economics literature on corporate law. The standard rationale for the existence of fiduciary duties and shareholder voting is that shareholders are the residual economic claimants in an incomplete contract with the corporation. ${ }^{21}$ Although that is true, there are many contractual claimants who might have residual economic interests in the corporation. As a result, the residual claimant theory often supplies few answers to difficult corporate law questions. This Part shows that the more important residual in corporate law is the residual of controlthe voting right-which is held uniquely by (usually common) shareholders. The shareholders, as the residual holders of these proprietary voting claims, are the proper focus of the residual claimant analysis for the purposes of corporate law.

21 See infra Section II.B. 
Part V surveys how the property theory could bear on both longstanding puzzles and emerging trends in corporate law. The most obvious application relates to the interpretation of charter provisions, which Delaware has increasingly characterized as contractual in nature. ${ }^{22}$ Additionally, the property theory sheds light on many other recurrent issues in corporate law, such as the fiduciary duties owed to non-shareholder claimants, the related question of the scope of fiduciary duties owed in (the zone of) insolvency, the problems raised by increasingly prevalent dual-class capital structures, and even the social purpose of the firm.

\section{THE CONTRACTUAL THEORY AND ITS LIMITATIONS}

The nexus of contracts theory views the corporation as a set of contracts among various contractual claimants. ${ }^{23}$ In this view, shareholders are merely one type of contract claimant, albeit a contract claimant with a distinctive type of contract. ${ }^{24}$ Interpreting the firm as a set of contracts makes the concept of ownership irrelevant, because the rights of all claimants, including shareholders, are defined by contract rather than property. Section II.A sets out how this contractarian approach developed as the economic theory of the firm. Section II.B shows how the literature on the theory of the firm was applied to legal theory in corporate law. Section II.C details the problems that the contractarian theory faces in explaining foundational rules of corporate law. This Part lays the foundation for Part III, which builds a property theory of corporate law.

22 See supra notes 59-62 and accompanying text.

23 See EASTERBROOK \& FischeL, supra note 2, at 12 (describing the corporation as a "nexus of contracts' or a set of implicit and explicit contracts").

24 See, e.g., Macey \& Strine, supra note 9, at 483-85 (describing stockholders as "fellow contract claimants" and "mere contractual counter-parties with the firms in which they have invested"). 


\section{A. The Contractual Theory of the Firm}

The starting place in tracing the intellectual lineage of the contractarian approach is Ronald Coase's The Nature of the Firm. ${ }^{25}$ In that work, Coase asked the fundamental question of why firms exist at all, as opposed to transactions being simply arranged by contracting through markets. ${ }^{26}$ In theory, an entrepreneur could simply enter into contracts with the suppliers of all necessary inputs to a production process, without the need for a "firm." In such a world, businesses could operate entirely through contracting, with no organization, no hierarchy, and no "internal" structure.

Yet in the real world, firms exist. Coase argued that firms arise because of the transaction costs associated with market exchanges, particularly the price mechanism. ${ }^{27}$ Entering into many contracts with various suppliers of inputs would be costly, driven perhaps most obviously by the cost of determining "what the relevant prices are" through the "price mechanism." 28 Thus, Coase argued that firms arise when entrepreneurs economize on transaction costs by shifting from contracting to employment relationships. ${ }^{29}$ In a hierarchical employment relationship, the firm does not need to negotiate the price of an input and the terms related to its production with an employee, it simply tells the employee what tasks to perform, saving on transaction costs. Some transactions, of course, will still take place through contracting in markets, but only where the transaction costs warrant such market contracts. In other transactions the firm economizes on transaction costs by allowing its internal hierarchy or fiat to take the place of a market exchange.

25 Coase, supra note 19.

26 Coase, supra note 19, at 390 ("Our task is to attempt to discover why a firm emerges at all in a specialised exchange economy.”).

27 Id. at 390-91.

$28 I d$. at 390 ("The main reason why it is profitable to establish a firm would seem to be that there is a cost of using the price mechanism. The most obvious cost of 'organizing' production through the price mechanism is that of discovering what the relevant prices are.").

29 See id. at 391. 
Coase's theory of the firm originated the nexus of contracts idea but did not describe a pure contractarian account. Instead, it specifically provided for non-market (intra-firm) transactions. ${ }^{30}$ The contractual perspective took its next step with Alchian and Demsetz's critique decades later. ${ }^{31}$ Alchian and Demsetz argued that relationships inside the firm are contracts just like those outside the firm. ${ }^{32}$ For example, an entrepreneur's relationship with an employee differs little from the entrepreneur's relationship with a contractor. In both cases the entrepreneur gives instructions, and the other party can either agree to the terms or not. In a sense, because all relationships in their model are contractual (as opposed to a mix of contract and hierarchy in Coase's formulation), Alchian and Demsetz are the originators of the nexus concept. ${ }^{33}$

The Alchian and Demsetz approach, although starkly contractarian, largely sidestepped the question of property in the corporation. The Alchian and Demsetz contractarian argument emerged against the backdrop of the Coasean dichotomy between "hierarchy" and "market/contract," not the legal distinction between property and contract. The Alchian and Demsetz model retained a traditional "owner" who combined residual rights and monitoring responsibility. ${ }^{34}$ Indeed, the paper contained a nearly full-page extended footnote about the concept of ownership that questioned the need for ownership to follow the equity interest, but without questioning the

30 Coase, supra note 19 , at 388.

31 See Armen A. Alchian \& Harold Demsetz, Production, Information Costs, and Economic Organization, 62 Am. ECON. REV. 777, 784-85 (1972).

32 Id. at 777 (arguing that the "power to settle issues" inside the firm is no different from that in "ordinary market contracting").

33 See Thomas S. Ulen, The Coasean Firm in Law and Economics, 18 J. CORP. L. 301, 319 (1993) (explaining that the Alchian and Demsetz approach "rather than that of Coase, gave rise to a vision of the modern corporation as an agglomeration of contractual relations, a view called the nexusof-contracts view").

34 See Alchian \& Demsetz, supra note 31, at 783 ("It is this entire bundle of rights: 1) to be a residual claimant; 2) to observe input behavior; 3 ) to be the central party common to all contracts with inputs; 4) to alter the membership of the team; and 5) to sell these rights, that defines the ownership (or the employer) of the classical (capitalist, free-enterprise) firm.”). 
idea of ownership itself. ${ }^{35}$ That issue was not at the forefront of the Alchian and Demsetz analysis, probably because their analysis did not account for an investor-financed company where control and residual rights are separated.

Jensen and Meckling tackled this latter question-of how investor financing affects the nature of the firm-in their classic article, Theory of the Firm: Managerial Behavior, Agency Costs and Ownership Structure. ${ }^{36}$ The main initial contribution of this path-breaking article, often credited with introducing the "nexus" concept, was to demonstrate how agency costs rise as outside financing increases. ${ }^{37}$ That is, Jensen and Meckling presented an essential piece for a theory of the complex firm - the agency costs that arise when a firm receives financing from outside investors. By introducing the essential concept of agency costs, over time Jensen and Meckling came to be seen as laying a microeconomic foundation for the organizational theory of the firm.

The most relevant point for present purposes is that the Jensen and Meckling approach conceives of the firm as purely contractual. ${ }^{38}$ From this perspective, all claims on the corporation are essentially contractual and "it makes little or no sense to try to distinguish those things which are 'inside' the firm (or any other organization) from those things that are 'outside' of it." 39 This marked a transition in the theory of the firm towards a potential theory of corporate law, because Jensen and Meckling included suppliers of capital, like shareholders, in their model. In other words, Jensen and Meckling escaped from the assumption of identity between shareholders and the "entrepreneur" in previous models, making a

\footnotetext{
35 As discussed more fully later, properly read, the Alchian and Demsetz footnote does not question the concept of corporate ownership. Instead, they expressly identify ownership with voting rights. The question they raise is whether that ownership (voting) should be mandatorily assigned to the residual owners. See infra notes 270-272 and accompanying text.

36 See Jensen \& Meckling, supra note 10, at 306.

37 See id. at 311 ("The private corporation or firm is simply one form of legal fiction which serves as a nexus for contracting relationships.").

38 Id. at 311.

39 See id.
} 
microeconomic theory of shareholders (and therefore corporate law) possible.

The culmination of the ownership skepticism in the theory of the firm arrived with Eugene Fama's Agency Problems and the Theory of the Firm. ${ }^{40}$ This work continued squarely in the nexus of contracts perspective to examine the separation of ownership and control, this time in the public corporation. ${ }^{41}$ The work begins by rejecting "the typical presumption that a corporation has owners in any meaningful sense." ${ }^{2}$ Fama does this because in many cases the widely dispersed shareholder base in the typical public corporation cannot exercise the "control over a firm's decisions" that most previous models attributed to "owners." 43 His model attempted to show that the "separation of security ownership and control can be explained as an efficient form of economic organization." 44 In other words, Fama's model eliminated the concept of ownership as an assumption, not a conclusion.

Taken together, these invaluable papers moved beyond studying the firm as a "black box" in a market economy. Instead, the new contractarian perspective examined the individual incentives of those inside the firm, establishing microeconomic foundations of organizational action. The microanalytic approach refrains from anthropomorphizing the firm, recognizing that the corporation is a "they" and not an "it." 45 It frees the theory of the firm from the baggage of the reified entity that presumably could not otherwise exist, allowing

40 Eugene F. Fama, Agency Problems and the Theory of the Firm, $88 \mathrm{~J}$. Pol. ECON. 288 (1980)

41 Id. at 289 (explaining that existing literature fails to account for large firms where ownership and control are separated, and setting forth a new thesis based on a "set of contracts" approach).

42 Id. at 289.

43 Id. at 290 ("Dispelling the tenacious notion that a firm is owned by its security holders is important because it is a first step toward understanding that control over a firm's decisions is not necessarily the province of security holders.").

44 Id. at 289.

45 Kenneth Shepsle famously made a similar observation for Congress. See Kenneth A. Shepsle, Congress Is a "They," Not an "It": Legislative Intent as Oxymoron, 12 InT'L REV. L. \& ECON. 239, 244 (1992). 
economists to study why economic arrangements in the firm take the forms they do.

But Coase's original query and the subsequent literature did not say much about corporate law, focusing instead on explaining economic organization. Corporate law does not govern the arrangements corporations have with suppliers other than suppliers of capital, and the arrangement business organizations have with their suppliers of capital lay outside Coase's analysis. As the contractual theory expanded to consider the question of outside investment, it began to encompass shareholders. The question shifted from why there are firms rather than markets bargaining for the factors of production to why there are firms rather than contracts in the market for capital. This shift made it possible to apply the theory of the firm as a theory of corporate law. Thus, the economic theory of the firm literature set the stage for a new contractarian theory that moved away from ownership in the corporation. The question was how that theory would account for the shareholder-focused legal institutions found in corporate law.

\section{B. The Contractual Theory of the Corporation}

The contractual theory of the firm is not the same as a contractual theory of the corporation as a legal entity, but it did not take long for the nexus of contracts theory of the firm to permeate the legal theory of the corporation. Although there were many points of entry into legal scholarship, the enormously influential work of Easterbrook and Fischel ${ }^{46}$ emerged as the most important and remains the classic work within the contractarian paradigm. This Article focuses on Easterbrook and Fischel as the point of departure and the touchstone for the contractarian model.

Easterbrook and Fischel take the nexus of contracts approach as their starting point and attempt to explain the legal institutions of corporate law. ${ }^{47}$ Their perspective on the corporation is purely contractual, viewing a state's corporate code

46 See generally EASTERBROOK \& FISCHEL, supra note 2.

47 Id. at 15. 
as nothing but a set of "off-the-rack" contract terms that reduce the cost of contracting among parties to a corporate contract. ${ }^{48}$ The assumptions of the nexus of contracts perspective allow for no differentiation to be made between the common stock as a property interest and other claims on the corporation arising in contract-under that view, the corporation is all contract:

\section{Shareholders are no more the "owners" of the firm than are bondholders, other creditors, and employees (including managers) who devote specialized re- sources to the enterprise, yet bondholders and employ- ees do not vote at all. All of these participants in the enterprise negotiate contracts, explicitly or implicitly, with the other participants, and they obtain voting rights only to the extent those rights are beneficial to the whole enterprise. ${ }^{49}$}

Thus, the legal institution of the corporation, in the nexus of contracts approach, arises entirely from contracts among the many claimants on the corporation.

Although Easterbrook and Fischel's work offers a comprehensive account of corporate law, for the purposes of this Article its attempts to explain voting rights and fiduciary duties are the most relevant. Easterbrook and Fischel faced a first challenge in explaining why directors owed shareholders fiduciary duties within the contractarian paradigm, and a second similar challenge in explaining shareholder voting rights. ${ }^{50}$ After all, contractual counterparties do not typically have fiduciary duties to one another, and there is no obvious reason why one group of contractual counterparties should have the monopoly right to vote on changes that affect all of them. Indeed, Alchian and Demsetz, also working within the

48 Frank H. Easterbrook \& Daniel R. Fischel, Voting in Corporate Law, 26 J. L. \& ECON. 395, 401 (1983).

49 Id. at 396.

50 They even acknowledged the difficulty upfront with the quip, "how do fiduciary duties sneak into these contracts." EASTERBROOK \& FISCHEL, supra note 2 , at 90 . 
contractarian paradigm, made the point that voting rights need not reside uniquely (or at all) with shareholders. ${ }^{51}$

Easterbrook and Fischel explain fiduciary duties and voting rights by reference to the residual economic risk-bearing character of common stock. Common shareholders are the residual economic claimants in that they are entitled to receive whatever residual remains after all debts are paid. ${ }^{52}$ Although in this view shareholders are contractual claimants like all others, they differ from other claimants in that contracts cannot be written in sufficient completeness to resolve all contingencies ahead of time. ${ }^{53}$ This contractual incompleteness leaves discretion with managers, whose interests might diverge from those of the residual claimants. ${ }^{54}$ This discretion disproportionately affects shareholders as residual economic claimants. Thus, voting rights and fiduciary duties "attach to the residual claim because the holders of these claims bear the marginal risks of the firm and so have the best incentives to make the optimal investment and management decisions." 55

Fiduciary duties, in Easterbrook and Fischel's perspective, are the corporate law version of the "hypothetical bargain" or "would have wanted" approach that is common to contractual gap filling in contract law and economics. ${ }^{56}$ In Easterbrook and Fischel's view, the content of fiduciary duties should approximate what parties would have negotiated for if contracting were costless. ${ }^{57}$ The shareholders' right to vote exists for the same reason: it is what the investors would have negotiated if the cost of negotiating and enforcing contracts were low

51 See infra notes 270-272 and accompanying text.

52 See EASTERBROOK \& FischeL, supra note 2, at 67-70.

53 See id. at 90-93.

54 See id. at 90-91.

55 Id.

56 See Ian Ayres \& Robert Gertner, Filling Gaps in Incomplete Contracts: An Economic Theory of Default Rules, 99 YALE L.J. 87, 89-90 (1989) (describing the "would have wanted" approach to default rules and Easterbrook and Fischel's embrace of that perspective).

57 EASTERBROOK \& FISCHEL, supra note 2, at 92 ("Socially optimal fiduciary rules approximate the bargain that investors and managers would have reached if they could have bargained (and enforced their agreements) at no cost."). 
enough. ${ }^{58}$ That is, Easterbrook and Fischel believe that shareholder residual claimants would have negotiated these protections had they been sufficiently contractible. Thus, fiduciary duties are a judicially crafted gap filling strategy that serves to maximize efficiency while economizing on transaction costs.

The linchpin in this argument is the residual character of shareholders' economic claim. All contracts for factors of production are incomplete, leaving discretion to managers that could potentially be adverse to the counterparty. Yet not all contracts activate fiduciary duties-much less voting rights. Shareholder contracts are different, in Easterbrook and Fischel's view, because of the residual nature of their claims. Moreover, common shareholders enter into contracts that are intentionally incomplete, in the sense that they do not even attempt to spell out the content of fiduciary duties in contractual terms. Thus, the combination of an open-ended contract with residual economic rights, according to Easterbrook and Fischel, explains the allocation of fiduciary duties and voting rights to shareholders.

The contrast with the "traditional" ownership perspective on the nature of shareholders' interests in the corporation is stark. The traditional view rationalizes fiduciary duties, at least in part, based on the property interests of shareholders in the corporation. ${ }^{59}$ In contrast, the nexus of contracts approach rationalizes fiduciary duties based on the residual claimant status of the beneficiaries of those duties, coupled with the phenomenon of incomplete contracting. For contractarians, fiduciary duties do not arise because of ownership; the nexus of contracts approach rejects the idea that shareholders hold property interests in the corporation, or that there are property interests in the corporation. ${ }^{60}$ As a result, the

58 See Easterbrook \& Fischel, supra note 48, at 398.

59 See Thomas Lee Hazen, The Short-Term/Long-Term Dichotomy and Investment Theory: Implications for Securities Market Regulation and for Corporate Law, 70 N.C. L. REV. 137, 203 (1991) (referring to the "traditional fiduciary model," in which "management holds its power in trust for the corporation's true owners-the shareholders").

60 See, e.g., Ronald J. Gilson \& Charles K. Whitehead, Deconstructing Equity: Public Ownership, Agency Costs, and Complete Capital Markets, 108 CoLum. L. REV. 231, 241 (2008) ("More recent scholarship has deconstructed 
contractarian perspective challenges the very foundations of corporate law, which draws sharp distinctions between shareholders and non-shareholder claimants.

The legal scholarship in corporate law adopted the contractarian perspective with alacrity as the law and economics movement gained ground in the academy. Among courts, acceptance was more incremental. Although Delaware courts have long described corporate charters as contracts, for years following the widespread acceptance of the contractarian perspective among legal scholars they continued to invoke traditional concepts of ownership side-by-side with contractarian thinking. ${ }^{61}$ However, in past few decades the contractarian perspective spread through the courts, to the point that the corporate charter and bylaws are regularly described as "contracts" in Delaware cases. ${ }^{62}$ As the contractarian perspective gradually squeezed out other perspectives, ownership skepticism has taken hold widely in the academy and among several prominent practitioners. ${ }^{63}$

Although the nexus of contracts metaphor has become pervasive, it has not eliminated the idea that common stock plays a special role in corporate law. Corporate law doctrine has not

the corporation into a 'nexus of contracts,' rejecting a characterization of the shareholder as 'owner' in favor of one in which the corporation is an equilibrium among actors, including shareholders, creditors, and managers, who bargain within a complex set of relationships with the corporate entity at the center.").

61 See, e.g., Malone v. Brincat, 722 A.2d 5, 9 (Del. 1998) (finding that directors have "the legal responsibility to manage the business of a corporation for the benefit of its shareholders owners").

62 See, e.g., Airgas, Inc. v. Air Prods. \& Chems., Inc., 8 A.3d 1182, 1188

(Del. 2010) ("Corporate charters and bylaws are contracts among a corporation's shareholders ....").

63 See, e.g., Martin Lipton \& William Savitt, The Many Myths of Lucian Bebchuk, 93 VA. L. REV. 733, 754 (2007) (describing shareholder ownership as a myth). Notably, as a citation for this proposition the authors cite Martin Lipton's article Election Contests in the Company's Proxy: An Idea Whose Time Has Not Come, which in turn cites as its authority Martin Lipton's even earlier article. See Martin Lipton \& Steven A. Rosenblum, Election Contests in the Company's Proxy: An Idea Whose Time Has Not Come, 59 Bus. LAW. 67, 72 (2003) (citing Martin Lipton \& Steven A. Rosenblum, A New System of Corporate Governance: The Quinquennial Election of Directors, 58 U. CHI. L. REV. 187 (1991)). 
subscribed to the "absolute contractualism" of the nexus of contracts approach, ${ }^{64}$ which would in theory lead courts to treat all types of claims on the corporation equally, distinguishing them only on their status as residual claimants. Instead, courts have nearly universally continued to draw lines between corporate and contract law based on the internal affairs doctrine, with the label "stock" typically serving as a rough dividing line. Yet courts have recognized that this rough dividing line is inadequate for some purposes. This is particularly apparent in the context of preferred stock, where the Delaware courts routinely distinguish between the contractual rights of preferred stockholders and their "fiduciary" rights. ${ }^{65}$

Thus, the move toward a contractarian theory is well established both in the academy and in the Delaware courts, where the most important corporate cases are decided. However, as discussed in the next Section, pure contractarian theory is difficult to square with basic principles of corporate law. The conception of a "free floating" nexus of different but equal contractual claims, unrooted in the firm ground of property law, finds little support in state corporation statutes. These statutes deal almost exclusively with the rights of shareholders, as does the common law, which for most purposes treats shareholders as owners. In addition, courts have continued to draw a line between contractual and fiduciary rights. The next Section highlights some of the many incompatibilities of contractarian theory with corporate law and practice.

\section{The Theory of the Firm versus the Legal Backdrop}

The contractarian theory, at least in its most literal sense of ownership skepticism, faces an uphill battle in explaining many important features of corporate law. It must first confront the fact that the "traditional" view tends to view

64 See William W. Bratton, The New Economic Theory of the Firm: Critical Perspectives from History, 41 STAN. L. REV. 1471, 1517 (1989) ("To sum up, the doctrinal theory of the corporate firm refutes the assertion that the corporation 'is contract.").

65 See infra Section V.B. 
shareholders as the "owners" of the corporation. ${ }^{66}$ Indeed, such a view is literally black letter law in the Model Business Corporation Act ("the MBCA"). ${ }^{67}$ This perspective is also prevalent among courts, which regularly describe shareholders as the "owners" of the corporation. 68 The question is whether these labels are merely convenient shorthand for a special type of contractual relationship or whether they are intended to be taken literally.

This Section explores the arguments for and against recognizing property rights and contract rights in corporations. The first subsection addresses arguments for and against a property view of shares relating property theory to shares of corporate stock. The second subsection addresses arguments for and against a contractual view of shares. This subsection relies principally on the misalignment between contract law principles and the distinctive features of corporate law. The discussion shows that from both perspectives the default rights of common stockholders fall decidedly on the property side of the property-contract borderline. However, the verdict is more nuanced than the traditional view that shareholders are "the owners" of the corporation. Shareholders have ownership interests through the corporation, some stronger, some weaker, as well as contractual interests, all of which depend on the particular claim in question. These nuanced features of the corporation as an ownership structure will be a key feature of the analysis in Parts III, IV, and V.

66 See Velasco, supra note 8, at 898-901 (describing shareholder ownership as the "traditional view").

67 In the Model Business Corporation Act ("the MBCA"), shares are defined as "the units into which the proprietary interests in a domestic or foreign corporation are divided.” Model Bus. CoRP. ACT $§ 1.40$ (AM. BAR Ass’N 2016). Given that "proprietary" means "[o]f, relating to, or holding as property," the MBCA clearly takes the position that shares are ownership interests. Proprietary, Black's Law Dictionary (11th ed. 2019).

68 See, e.g., N. Am. Catholic Educ. Programming Found., Inc. v. Gheewalla, 930 A.2d 92, 101 (Del. 2007) (quoting Malone v. Brincat, 722 A.2d 5, 9 (Del. 1998)). 


\section{Common Stock and Property Theory}

How do the attributes of corporate stock mesh with the defining features of property? The property theory literature supplies many approaches for defining property, but the contemporary starting place is often with the "bundle of rights" perspective, drawing on A.M Honoré's classic exposition of the eleven incidents of ownership. ${ }^{69}$ This approach, although wellestablished within the property literature, has been challenged by the "new essentialism" in property that identifies several essential features of property. ${ }^{70}$ This Part first shows how corporate ownership interests align with the "bundle" metaphor associated with Honoré, before focusing the inquiry on the "essentialist" literature in Section III.B.

The incidents of ownership, according to Honoré, include: (1) the right to possess; (2) the right to use; (3) the right to manage; (4) the right to the income of the thing; (5) the right to the capital; (6) the right to security; (7) the incident of transmissibility; (8) the incident of absence of term; (9) the prohibition of harmful use; (10) liability to execution; and (11) the incident of residuarity. ${ }^{71}$ The various aspects of ownership on Honoré's list show that ownership can be more complex than traditional fee simple ownership, and that shareholders cannot be thought of as owners of the assets of the corporation in the same ways a fee simple owner would be.

Ownership skeptics often seize on this fact, deploying this list of the attributes of fee simple ownership to observe that shareholders lack some of these incidents and thereby conclude that the missing incidents testify to a lack ownership. ${ }^{72}$ The ownership skeptics are correct-shareholders do lack

69 See A. M. Honoré, Ownership, in OxFOrd Essays In JURISPRUdEnCE 107 (A. G. Guest ed., 1961).

70 See Katrina M. Wyman, The New Essentialism in Property, 9 J. LEGAL ANALYSIS 183, 184 (2017).

71 Id. at $113-34$

72 See, e.g., Kent Grennfield, The Failure of Corporate LAW 45 (2006) (arguing that shareholders "have fewer ownership 'rights' than virtually any other kind of owner"); Richard A. Booth, Who Owns a Corporation and Who Cares?, 77 CHI.-KENT L. REV. 147, 163-65 (2001) (arguing that because poison pill shareholders only have veto rights over a sale of the company they are not similar to owners). 
some of these incidents, at least as to the property legally owned by the corporation. As an example, shareholders typically lack the right to use corporate property, ${ }^{73}$ at least without authorization. They generally lack the right qua shareholders to manage, at least directly, especially when compared to the management rights of the board of directors. ${ }^{74}$ Thus, some important rights that inhere in property are, at least on the surface, absent in shares qua shares.

On the other hand, shareholders do have the strongest claim of any claimant to the right to the income of the firm, the right to capital, the right to security, the right to transmissibility, the right to absence of term, ${ }^{75}$ and the incident of residuarity. That is not to say that shareholders have each of these rights in the plenary form that an owner in fee simple does, but they do have these rights to a greater extent than any other corporate constituency. And that is exactly what ownership is for Honoré: the "greatest possible interest" in terms of the incidents he identified. ${ }^{76}$

There are only three rights to which shareholders do not clearly have the strongest claim, ${ }^{77}$ at least in terms of their

73 See, e.g., Daniel J.H. Greenwood, Person, State, or Not: The Place of Business Corporations in Our Constitutional Order, 87 U. CoLO. L. REV 351, 383 (2016).

74 An argument could be made that the directors own the corporation. See Velasco, supra note 8, at 911 n.69 (2010). This view has been dismissed by saying that directors can't act as owners because they can't "take [corporate assets] for personal use or consumption." Id. But this falls into the same trap as those who argue that shareholders don't own the corporation. Velasco does then note that although directors may use corporate assets only in "the performance of their duty," this undercuts their right to use the assets, not the relation of the right to use to ownership. See id.

75 Other contracts that parties have with a corporation have a term after which they terminate. This is even true of directors, who have annual terms or multi-year terms in the case of classified boards. See DEL. CoDE ANN. tit. 8, § 141(d) (2019).

76 Honoré, supra note 69, at 108.

77 It is not entirely clear that shareholders have the liability to execution, at least as to the assets held by the corporation. See infra Section III.C.1. However, as is clear from its name, this incident is not a "right", but rather a liability. Furthermore, the reason shareholders don't have this liability is because of a property-like right often called "affirmative asset partitioning" discussed in Section III.C, infra. 
direct rights. Shareholders' right to use, right to possess, and right to manage all are limited. However, Honoré's incidents are not all individually necessary to find ownership. ${ }^{78}$ As to the right to use, it is easily seen that the present right to use an asset in the personal consumption sense is not essential to ownership. Just consider a landlord who leases her property. Such a landlord would have no present right to use the property during the term of the lease, but she would still retain a strong claim of ownership. Similarly, many types of assets have multiple owners in which control is structured vertically and centralized in managers. ${ }^{79}$ Common interest communities such as homeowners' associations, condominiums, and cooperatives involve ownership even though unlimited use is not available to each owner. ${ }^{80}$ Moreover, as developed more fully below, the argument for "use" overlooks the fact that usage restrictions exist for the benefit of other owners who do not want shareholders to use the property in certain ways.

More importantly, shareholders as a whole do have all of these rights, at least indirectly. In the most important corporate law jurisdictions, shareholders can dissolve the corporation without the concurrence of the board of directors. Specifically, in California and New York a majority of the shareholders can dissolve the corporation without the board's consent. ${ }^{81}$ Even Delaware allows dissolution without the board, though it requires a unanimous shareholder vote. ${ }^{82}$

78 See Honoré, supra note 69, at 112-13 (“[T] he listed incidents are not individually necessary . . . conditions for the person of inherence to be designated 'owner' of a particular thing in a given system. As we have seen, the use of 'owner' will extend to cases in which not all the listed incidents are present.").

79 This is often a characteristic of multiple-owner property, which has been called "governance property." See Gregory S. Alexander, Governance Property, 160 U. PA. L. REV. 1853, 1856, 1866-73 (2012).

80 For this comparison, see Jane B. Baron, Rescuing the Bundle-ofRights Metaphor in Property Law, 82 U. CIN. L. REv. 57, 80-81 (2013).

81 See CAL CorP. CODE $\S 1900(a)$ (West 2018); N.Y. Bus. CorP. LAW $\S$ 1001(a) (McKinney 2019).

82 See Del. Code AnN. tit. 8, § 275 (2019). Delaware law required board action to dissolve the corporation prior to 1969 , but created a procedure not requiring board action in that year. See Act of June 23, 1969, 57 Del. Laws ch. 148, §§ 31-32 (codified as amended at DEL. CoDE ANN. tit. 8, § 275 
Thus, shareholders in these states have the right to take hold of and use corporate property for any purpose, though that right may only be exercised collectively and indirectly. The MBCA has a different rule, requiring the concurrence of the board and shareholders to dissolve, ${ }^{83}$ but shareholders can always remove directors who disagree with their plan. ${ }^{84}$

The unilateral power to dissolve the corporation is a powerful incident of property, akin to forcing an accounting or partition of property owned in co-tenancy. Not only does this mean that shareholders can take corporate assets out of corporate solution, it also parallels the ancient "right to destroy" as an incident of property rights. ${ }^{85}$ This right of the shareholders to remove assets from corporate solution is not addressed by contractarian scholars, and strongly points toward finding that shareholders retain an ownership interest when they put assets into the corporation.

The right to manage and the right to possess are related in the corporate context in a way that illuminates the property dimension of the corporation. The right to possess is primarily the right to exclude others from use, and the right to manage resides formally in the board. ${ }^{86}$ But shareholders as a whole can exclude the board by removing them or electing others. ${ }^{87}$ The fact that shareholders as a whole can toss aside any of the limitations on direct management shows that those limitations were designed for the benefit of the shareholders themselves, not other constituencies such as creditors. The reason why shareholders do not have these rights individually is not to protect the interests of other parties; it is to protect the interests of the shareholders. The limitations on shareholder

(2019)). These provisions were replaced with new provisions in 1987, but the statute retained this stockholder-only alternative to dissolution by the joint board-stockholder action. See Act of July 1, 1987, 66 Del. Laws ch. 136, $\S 34$ (codified as amended at DEL. CODE ANN. tit. 8, § 275 (2019)).

83 Model Bus. CORP. ACT $§ 14.02$ (AM. BAR Ass'N 2016).

84 Id. $\S 8.08$.

85 See, e.g., Lior Jacob Strahilevitz, The Right to Destroy, 114 YALE L.J. 781, 781-87 (2005) (tracing the "right to destroy" as an incident of ownership from Roman law to the present).

86 Del. Code ANN. tit. 8, § 141(a) (2019).

87 Id. $\S 141(\mathrm{k})$. 
control are de facto ones, not legal ones, and the few procedural legal limitations exist to protect shareholders themselves.

The last two points-the ability of the shareholders to dissolve the corporation and take its assets directly and the ability of shareholders to remove managers-often prompts the response that such actions are not feasible because of the lack of de facto control of individual shareholders in a widely held corporation. ${ }^{88}$ The ownership skeptic argues that it is not practical (or perhaps even possible) in a widely held company to recruit a majority of shareholders to vote to take control of the assets of the corporation. Thus, the debate over ownership ultimately comes down to the commonly voiced argument that the lack of de facto control by individual shareholders defeats their status as property owners. This Article calls this argument the "control thesis."

The debate over the control thesis is clarified by first considering polar opposite corporations: public corporations and private corporations with single shareholders. Even those skeptical of ownership interests in public corporations would generally concede that a sole shareholder in a private corporation owns a property interest in the corporation. ${ }^{89}$ Public corporation shareholders have very limited control rights, and therefore lack the practical ability to exercise incidents of ownership. ${ }^{90}$ But the sole shareholder of a private corporation

88 See, e.g., Lucian A. Bebchuk, The Myth of the Shareholder Franchise, 93 VA. L. REV. 675, 688-94 (2007) (noting that the high costs of proxy contests and the existence of staggered boards are obstacles to shareholders' ability to replace management through the franchise).

89 See Lynn A. Stout, Bad and Not-so-Bad Arguments for Shareholder Primacy, 75 S. CAL L. REV. 1189, 1191 (2002) ("Thus, while it perhaps is excusable to loosely describe a closely held firm with a single controlling shareholder as 'owned' by that shareholder, it is misleading to use the language of ownership to describe the relationship between a public firm and its shareholders."). She then says "it is even questionable, from an economic perspective, to say that a single controlling shareholder 'owns' a closely held firm after the firm has issued debt." Id. at 1191-92.

90 See Velasco, supra note 8, at 907-12 (2010) (addressing the common argument that shareholders lack ownership because they lack control, and concluding shareholders do have the type of control one would expect from 
has complete control, and therefore, under the control thesis, has ownership.

The argument that ownership turns on control is facially appealing, but it is difficult to square its conception of shareholders as mere risk-bearers with an actual series of corporate transactions. The nexus of contracts model is one in which "[c]ommon shareholders sell their risk bearing services to the corporation." 91 This is helpful as an "as if" model in economic analyses, but from a legal perspective it runs into serious difficulties. The perspective of common shareholders "selling" risk-bearing services makes some functional sense if the public corporation is taken as a given, but becomes incoherent when each step of the analysis is examined incrementally.

The point is starkly made simply by considering a new business run as a sole proprietorship. A sole proprietorship is as much a "firm" in the economic sense as is a corporation, at least if it has employees. ${ }^{92}$ Thus, many of the arguments rooted in the theory of the firm about why a public corporation is a nexus of contracts also applies to other business forms, such as partnerships, LLCs, and even sole proprietorships. ${ }^{93}$ In the sole proprietor case, all agree that the sole proprietor owns the business assets directly. Has the sole proprietor sold "risk bearing services" to the proprietorship? Few would argue that she has, in part because no one else has an equity interest in the business.

Consider then a slightly stronger case for viewing an equity holder as "selling risk bearing services," as scholars skeptical of corporate ownership describe shareholders. ${ }^{94}$ The sole

joint owners). Velasco rejects this "control" argument as unpersuasive. Id. at $907-10$.

91 Henry N. Butler, The Contractual Theory of the Corporation, 11 GEO. MASOn L. REV. 99, 107 (1989).

92 See supra Section II.A (explaining that the essence of the Coasean firm was the use of hierarchy or "fiat" over employees, rather than the use of the market).

93 See Velasco, supra note 8, at 921 ("Smaller corporations, closely held corporations, limited liability companies, partnerships, even sole proprietorships-all of them fall within the description, nexus of contracts.").

94 See, e.g., Daniel J.H. Greenwood, Fictional Shareholders: For Whom Are Corporate Managers Trustees, Revisited, 69 S. CAL. L. REV. 1021, 1034 n.24 (1996). 
proprietor could theoretically sell a $1 \%$ stake in the underlying assets of the business to ninety-nine investors, retaining only $1 \%$ for themselves. Without an entity, ${ }^{95}$ the original sole proprietor would still be a co-owner of the assets, not a contract claimant. The resulting structure would be a mess, but it would be a property mess. If, on the other hand, the original $100 \%$ owner organized a corporation and then sold off the $1 \%$ stakes, contract theorists would be more likely to see the resulting structure as a nexus of contracts.

What is the difference between the two scenarios? The difference is not the lack of control by the original entrepreneur, because the original entrepreneur lost control in both cases. The difference is the creation of the corporate entity. Yet, according to the control thesis, the wholly owned corporation that resulted from incorporation would still have all the attributes of property in the hands of the $100 \%$ shareholder. If the sole shareholder sold off the same $99 \%$ interest (now in the form of corporate shares), the argument of the control thesis would require that the retained $1 \%$ be transmuted from a property interest into a contract right. If there is an event that converts property interests into contract interests, it is incorporation itself, but relying on incorporation in this way defeats the argument that control is central to shareholders' ownership interests.

All of this displays the weakness of the control thesis. The practical inability to exercise a property right does not convert it into a contract right. If dividing ownership of property into many hands (thereby eliminating effective control) can convert property rights into contract rights, then presumably reunifying splintered contract rights into a single owner would convert them into property. Accepting that premise, shares held by a single shareholder could flip back and forth between being construed as representing contract and property interests as other shareholders traded their shares. However, such a property-contract conversion does not generally result when

95 Such an arrangement likely would constitute a general partnership, which is created when there is "an association of two or more persons to carry on as co-owners of a business for profit." UNIF. P'SHIP ACT § 102(11) (Nat'l Conference of Comm'rs on Unif. State Laws 2013). 
property is divided or when contract rights held by many parties are unified in one person's hands. The owners of property can divide ownership into as many pieces as they desire without converting the property rights into contract.

Because merely dividing property into widely held shares does not transmute property interests into contract rights, a shareholder of a widely held corporation holds the same type of interest as a shareholder of a closely held corporation. In other words, if a corporation with one shareholder is owned by its shareholder, then all corporations are owned by shareholders. And if a widely held corporation is merely a nexus of contract rights, then so is the corporation with one shareholder who holds $100 \%$ of the corporation's shares. Incorporation itself is the only event that could convert property rights into contract rights, yet incorporation is not viewed as making that transformation, and such an explanation would conflict with the control thesis.

Another argument against property rights in the corporation relies not on the number of shares into which equity is sliced, but on the necessity of many different types of inputs to production. Any business corporation depends on the contributions of many constituents. Some contribute property, some contribute labor, others contribute capital. Each of them expects to be compensated for their contribution, and each of them is necessary to conduct the business. Therefore, one might conclude that because several different contributions are jointly necessary for production, no single input (such as the capital input of common stock) can claim ownership of the corporation. ${ }^{96}$ Indeed, one might think that the contribution of shareholders is less essential than others because capital is fungible.

This argument falls apart by a logic similar to that applied to the control thesis. Consider a newly formed corporation that has no operations; such a corporation has no inputs other than capital from common shareholders. As a result, there is no argument that anyone but shareholders hold an ownership interest in the corporation. As the corporation grows, employees are hired, and contracts are made with suppliers and

96 See GreEnFIELD, supra note 72, at 46. 
customers, do the ownership interests of the shareholders thereby convert into contract rights? The flaw in this argument is in confusing a business with a corporation. It is true that a business is not much of a business without all the many contributions of various constituents. But a corporation can be a corporation without operating a business with other constituents-although a (stock) corporation cannot be a corporation without shareholders. ${ }^{97}$

One of the more complex objections to the property view comes from corporate law itself. A key feature of the corporate form is that shareholders generally do not have the ability to directly command the board to take a particular action. ${ }^{98}$ This is true even when shareholders use their inalienable right to unilaterally enact bylaws. ${ }^{99}$ That is, shareholders are limited in their ability to use their bylaw "contract" to constrain the discretion of the board in managing the company. ${ }^{100}$ The fact that directors are not required to obey the instructions of a majority of shareholders would seem to argue against a property conception. There are two responses to this, however.

First, it may be argued that this is a limitation only on procedure, not substance. Shareholders can generally remove directors at any time, and they are permitted to remove directors because of how they manage the business. ${ }^{101}$ Shareholders can simply remove a disobedient director and install another one. Shareholders generally have no duties in

97 Nonstock corporations have very different attributes and are discussed infra Section III.B.

98 See Paramount Commc'ns Inc. v. Time Inc., Nos. 10866, 10670, 10935, 1989 WL 79880, at *30 (Del. Ch. July 14, 1989) ("The corporation law does not operate on the theory that directors, in exercising their powers to manage the firm, are obligated to follow the wishes of a majority of shares."), aff'd, 571 A.2d 1140 (Del. 1989).

99 See, e.g., CA, Inc. v. AFSCME Emps. Pension Plan, 953 A.2d 227, 239-40 (Del. 2008).

100 See Jill E. Fisch, Governance by Contract: The Implications for Corporate Bylaws, 106 CALIF. L. REV. 373, 383-87 (2018) (discussing the implications of the AFSCME decision in limiting the ability of shareholderadopted bylaws to dictate how the board exercises its management responsibilities).

101 Del. Code AnN. tit. 8, § 141(k) (2019). 
the exercise of that discretion, and therefore could remove directors for any reason, including disobedience.

A second argument is that this limitation is actually a limit on contract rights and a feature of the corporation as an ownership structure. Board-centric management is a rational way for shareholders to pre-commit to fiduciary duties, given that shareholders themselves do not generally owe fiduciary duties to each other. ${ }^{102}$ Because non-controlling shareholders do not owe fiduciary duties to anyone, if directors had a "duty to obey," then a majority of such shareholders could simply instruct the board how to act and thereby eliminate the board's duty to the rest of the shareholder base. Thus, the limitation on shareholders' ability to dictate board decision making is a rational pre-commitment to protect minority shareholders from majority overreaching, and is actually essential to the property-like feature of shareholders having no duties, of good faith or otherwise, to anyone.

In other words, the mandatory structure of the board's decision making role is a way of protecting the property rights of the minority shareholders. The board does not have an obligation to obey the wishes of the majority shareholder. ${ }^{103}$ The fact that the board need not take instructions from the majority is a protective feature for the minority's property interests. Indeed, such a protective feature is far more reminiscent of trust than it is of contract.

In summary, the usual arguments of ownership skeptics rely on a common rhetorical device. They apply a restrictive

102 See Theodore N. Mirvis et al., Bebchuk's "Case for Increasing Shareholder Power": An Opposition, 120 HARV. L. REV. F. 43, 51 n.24 (2007).

103 As then-Vice Chancellor Strine memorably put it, "[d]irectors are not thermometers, existing to register the ever-changing sentiments of stockholders. . . . During their term of office, directors may take good faith actions that they believe will benefit stockholders, even if they realize that the stockholders do not agree with them." In re Lear Corp. S'holder Litig., 967 A.2d 640, 655 (Del. Ch. 2008) (citations omitted). See also Paramount Commc'ns Inc. v. Time Inc., Nos. 10866, 10670, 10935, 1989 WL 79880, at *30 (Del. Ch. July 14, 1989) ("The corporation law does not operate on the theory that directors, in exercising their powers to manage the firm, are obligated to follow the wishes of a majority of shares. In fact, directors, not shareholders, are charged with the duty to manage the firm."), aff'd, 571 A.2d 1140 (Del. 1989). 
view of ownership by holding up the case of the sole fee simple owner of physical property, then showing that the rights of shareholders fall short of that standard. Such an argument merely shows that shareholders are not "the owners" of the corporation in the Blackstonian sense that they retain "sole and despotic dominion ... in total exclusion of the right of any other individual in the universe." 104 But it does not negate that shareholders maintain some property interests in the corporation. One need not hold all incidents of ownership to have a property interest. One can hold an ownership interest in property without being "the owner" of that property in the Blackstonian sense. The fact that shareholders may not exercise all the incidents of ownership does not mean the shares are not ownership interests. ${ }^{105}$ The next Section shows the incompatibility of corporate law with a contract view of share ownership.

\section{Problems with Common Stock as Contract}

The conception of the corporation as a creature of contract strains the contractual model from the outset. Parties to contracts normally have contractual obligations or contractual rights (usually both). But stockholders have no obligations to the corporation (or anyone else) by virtue of being a stockholder, and often have not provided any consideration to the corporation. ${ }^{106}$ Of course, they may have such contractual obligations or rights pursuant to other agreements they enter into, such as voting agreements, but not by virtue of owning stock. So perhaps one could think of stock as a contract in which shareholders have no obligations but only rights-essentially a unilateral contract. But in reality, shareholders also have no specific rights to receive anything from the

1042 WiLliam BLACKSTONE, COMMENTARIES ON THE LAWS OF ENGLAND 2 (Univ. Chi. Press 1979) (1766).

105 Eisenberg, supra note 1, at 825-26.

106 See Ann M. Lipton, Manufactured Consent: The Problem of Arbitration Clauses in Corporate Charters and Bylaws, 104 GEo. L.J. 583, 602 (2016) ("Most shareholders-especially those who buy on the secondary market-owe no duties to the corporation and have offered no consideration to it."). 
corporation, making the corporation an "odd creature" when viewed as a contract. ${ }^{107}$

The corporate "contract" with shareholders can also be amended over the objection of some or most of the "parties," by amending the corporate charter or bylaws, as well as by changing the relevant corporate statute or applicable case law. The idea of unilateral amendments to the "contract" between the corporation and its shareholders raises a number of puzzling issues. ${ }^{108}$ The fact that the "contract" can change without assent from or even notice to all the "parties" seems incongruous (but not entirely unheard of) as a matter of contract law. ${ }^{109}$ But this makes more sense, however, when one realizes that the mechanism for changing the corporate "contract" are not really contract-based rules; they are more analogous to trusts. ${ }^{110}$

The contractarian theory excels in explaining why so few mandatory rules exist in corporate law, however it struggles to explain the few but foundational mandatory rules that do exist. The most foundational mandatory rule is the limited number of organizational forms from which entrepreneurs may select. ${ }^{111}$ The relatively small number of standardized forms derives more from the "numerus clausus" concept in property law than the infinite variability principle of contract law. ${ }^{112}$

Moving beyond organizational form, probably the most well-known and difficult problem for the contractarian theory is the existence of mandatory fiduciary duties, obligations uncommon in contract but standard in property-like settings such as trust law. ${ }^{113}$ Another challenge for the contractarian

107 Id.

108 See Albert H. Choi \& Geeyoung Min, Contractarian Theory and Unilateral Bylaw Amendments, 104 IowA L. REV. 1, 21-32 (2018) (discussing the application of contract principles to unilateral bylaw amendments).

109 See Lipton, supra note 106, at 603-05.

110 See id. at 587.

111 See id. at 619.

112 See id. at 619 (explaining how the limited number of standardized entity forms resembles the limited number of tenancies in property law).

113 There is debate about whether trust law should be thought of as contract or property. See John H. Langbein, The Contractarian Basis of the Law of Trusts, 105 YALE L.J. 625, 671 (1995). 
approach is explaining the many in rem features of the corporate entity, which are nearly unknown in contract but ubiquitous in property. ${ }^{114}$ These and other tensions between corporate law and contractarian theory are the subject of this Section.

As described above, Easterbrook and Fischel reason that fiduciary duties arise because of the open-ended nature of corporate contracts, combined with their residual claimant status. ${ }^{115}$ Indeed, the common stock "contract" is just about as open-ended as can be with respect to common stockholders, generally having few or no explicit terms. ${ }^{116}$ The corporate charter prescribes rules of governance but does not define any specific economic rights of the common stockholders. ${ }^{117}$ As a result, the contractarian perspective conceives of the common stockholder relationship with the corporation as a contract with no explicit terms. The only rights are those "off-the-rack" default contract law rights provided by the state.

In the nexus of contracts approach, the fact that the corporate contract does not contain specific terms motivates the imposition of fiduciary duties on directors. But contracts do not generally create fiduciary duties, ${ }^{118}$ even when contracts are

114 Thomas W. Merrill \& Henry E. Smith, What Happened to Property in Law and Economics?, 111 YALE L.J. 357, 360 (2001) (explaining that "[p]roperty rights historically have been regarded as in rem").

115 See supra Section II.B.

116 See infra Section V.A.

117 Indeed, as explained in Section IV.B, infra, it is often incoherent to set out economic rights of the residual economic interest in the corporation.

118 See, e.g., Saint Bernard Sch. of Montville, Inc. v. Bank of Am., 95 A.3d 1063, 1078 (Conn. 2014) ("[A] mere contractual relationship does not create a fiduciary or confidential relationship."). Delaware courts have considered whether contracts create fiduciary duties in various contexts (even in open-ended contexts such as that of the insurer-insured, and plan administrator-participant), and found none. See Crosse v. BCBSD, Inc., 836 A.2d 492, 497 (Del. 2003) (finding that a health services corporation did not owe a fiduciary duty to plan participants). The Delaware Supreme Court had previously held that:

The concept of a fiduciary relationship, which derives from the law of trusts, is more aptly applied in legal relationships where the interests of the fiduciary and the beneficiary incline toward a common goal and in which the fiduciary is 
open-ended or leave discretion to a party. Instead, that is where the duty of good faith and fair dealing steps in. For example, at-will employment relationships are often formed without a written contract, and yet employers do not owe fiduciary duties to their employees. ${ }^{119}$ Employees may owe fiduciary duties to employers, but not because of the open-endedness of the contract; it is because of their status as agents. ${ }^{120}$ Indeed, the employee example actually points the other way. Some employees, like corporate officers, may have fiduciary duties because they are entrusted with the ability to alter the legal relations of their employer, often implicating the employer's property, and those duties are imposed without regard to the open-endedness of the employment contract. ${ }^{121}$

There is another problem with the idea that contractual incompleteness leads to the imposition of fiduciary duties. Just as the corporate contract contains no terms as to how directors will exercise their discretion, it also contains no terms as to how shareholders will exercise their discretion-such as voting, enacting bylaw amendments, nominating board members, and so forth. So, under the nexus of contracts rationale, one would expect that shareholders would also have fiduciary duties, at least within these spheres. Yet shareholders qua shareholders have no duties, fiduciary, good faith, or

required to pursue solely the interests of the beneficiary in the property.

Corrado Bros. v. Twin City Fire Ins. Co., 562 A.2d 1188, 1192 (Del. 1989) (citation omitted). Crosse held that such an implication of a fiduciary duty did not exist where the parties' interest "are not perfectly aligned." See Crosse, 836 A.2d at 495 . Although it is unlikely that the court literally required "perfect alignment" of interests (otherwise, what point would the fiduciary duty serve?) it is clear that Delaware requires a high standard to imply fiduciary duties from a contractual relationship.

119 See, e.g., Wynn v. Wachovia Bank, N.A., No. 3:09CV136, 2009 WL 1255464 , at *5 (E.D. Va. May 6, 2009) ("[W]hile an employee owes a fiduciary duty to an employer, no corresponding duty is imposed on the employer.").

120 See Restatement (Third) Of Agency $§ 8.01 \mathrm{cmt}$. c (Am. LaW Inst. 2006).

121 See id. 
otherwise, especially in how they exercise their voting discretion. ${ }^{122}$ The same is true even for controlling shareholders under many circumstances. ${ }^{123}$ Thus, there is something asymmetric about the relationship between shareholders and directors that does not mesh with the fiduciary duty rationale, or even the idea that shareholders hold contract rights. ${ }^{124}$

Another incongruity for the contractual view of the corporation is the mandatory nature of common stock itself under corporation codes. Although corporations generally enter into contracts, they need not enter into any contracts to have a valid de jure existence. In contrast, common stock must be authorized in the charter document in order to complete a valid incorporation. ${ }^{125}$ Indeed, common stock is the only claim on the corporation with this special importance under corporate codes. Similarly, a corporation could eliminate all of its contractual arrangements by agreement with its counterparties without violating any rules of corporate law. But it cannot extinguish all of its common stock, even by mutual agreement, because corporate statutes require a residual interest of some form in all stock corporations. For example, the Delaware

122 Ringling Bros.-Barnum \& Bailey Combined Shows, Inc. v. Ringling, 53 A.2d 441, 447 (Del. 1947) ("Generally speaking, a shareholder may exercise wide liberality of judgment in the matter of voting, and it is not objectionable that his motives may be for personal profit, or determined by whims or caprice ....").

123 See Williams v. Geier, 671 A.2d 1368, 1380-81 (Del. 1996) ("Stockholders (even a controlling stockholder bloc) may properly vote in their own economic interest.”); Ford v. VMware, Inc., C.A. No. 11714-VCL, 2017 WL 1684089, at *15 (Del. Ch. May 2, 2017) ("Delaware courts consistently have held that a controlling stockholder's fiduciary duty does not constrain its ability to vote its shares.").

124 This is because counterparties to contracts have duties of good faith and fair dealing to one another that cannot be eliminated, while shareholders have no such duties. See Mohsen Manesh, Creatures of Contract: A HalfTruth About LLCs, 42 DEL. J. CoRP. L. 391, 421-24 (2018) (describing the duty of good faith as a mandatory rule of corporate law).

125 See Model Bus. CorP. ACT $§$ 6.01(b) (AM. BAR Ass’n 2016) (“The articles of incorporation must authorize: (1) one or more classes or series of shares that together have full voting rights, and (2) one or more classes or series of shares (which may be the same class, classes or series as those with voting rights) that together are entitled to receive the net assets of the corporation upon dissolution."). 
General Corporation Law ("the DGCL") provides that a corporation may redeem its shares, but it must be the case "that immediately following any such redemption the corporation shall have outstanding 1 or more shares of 1 or more classes or series of stock, which share, or shares together, shall have full voting powers."126 The MBCA contains a similar provision. ${ }^{127}$ Both statutes require that shares with full voting power continue to exist at all times. Why is this requirement present for voting stock, and not for any other claim on the corporation?

One reason at least some stock with full voting powers is mandatory is that otherwise the board would become self-perpetuating. The board of directors in such a circumstance would assume a much more significant role, as such a corporation would essentially be "unowned." ${ }^{28}$ Indeed, such corporations do exist in the form of nonprofits, as discussed more fully below. ${ }^{129}$ But in for-profit corporations, corporation statutes make the existence of voting stock mandatory, something that is true of no other type of claim on the corporation-certainly no contractual claim. It is notable that what is universally mandatory is not necessarily that a residual claimant in the economic sense remain outstanding; it is that stock with "full voting powers" remain outstanding. ${ }^{130}$ This difference between the voting residual and the economic residual becomes important in Part IV, infra.

The view that residual voting power holds a unique role is further supported by the protections it has from certain incursions of the board. These protections derive not from any

126 Del. Code AnN. tit. 8, § 151(b) (2019).

127 Model Bus. CoRP. ACT § 6.03(c) (AM. BAR Ass’N 2016) (“At all times that shares of the corporation are outstanding, one or more shares that together have full voting rights and one or more shares that together are entitled to receive the net assets of the corporation upon dissolution must be outstanding.").

128 See infra notes 179-183 and accompanying text.

129 See infra Section III.B.

130 As noted above, the MBCA and the DGCL differ in this regard, as the DGCL requires only stock with full voting rights to remain outstanding, while the MBCA requires stock with full voting rights and residual economic rights to remain outstanding. Compare DEL. CODE ANN. tit. 8, § 151(b) (2019), with Model Bus. CoRP. ACT § 6.03(c) (AM. BAR Ass’n 2016). 
explicit or default contractual arrangement, but by mandatory corporate law. For example, Delaware prohibits attempts by directors to interfere with the voting rights of shareholders through bylaw amendments. In Delaware, the stockholders have the right to unilaterally amend the bylaws without the need for director approval, ${ }^{131}$ a right that cannot be taken away. ${ }^{132}$ Directors also have the right to unilaterally amend the bylaws, but only if authorized in the corporation's certificate of incorporation. ${ }^{133}$

The protections against interference with the shareholder franchise are special in corporate law. Interference by the board with the corporate franchise receives enhanced scrutiny not applied to other decisions affecting shareholders' rights. ${ }^{134}$ Bylaws prohibiting the stockholders from removing directors without cause are invalid. ${ }^{135}$ Likewise, bylaws imposing a supermajority requirement for the removal of directors are invalid. ${ }^{136}$ These rules reflect the special connection that shareholder voting has to corporate law and fiduciary duties.

Further, shareholders' voting power is protected by a mandatory "property rule" in its execution. ${ }^{137}$ There is no notion of an "efficient breach" of the voting rights held by common

131 DeL. CoDE ANN. tit. 8, § 109(a) (2019) ("After a corporation other than a nonstock corporation has received any payment for any of its stock, the power to adopt, amend or repeal bylaws shall be in the stockholders entitled to vote.").

$132 I d$. ("The fact that such power has been so conferred upon the directors or governing body, as the case may be, shall not divest the stockholders or members of the power, nor limit their power to adopt, amend or repeal bylaws.”).

$133 I d$. ("[A]ny corporation may, in its certificate of incorporation, confer the power to adopt, amend or repeal bylaws upon the directors . ...").

134 See Blasius Indus., Inc. v. Atlas Corp., 564 A.2d 651, 659 (Del. Ch. 1988).

135 In re VAALCo Energy, Inc. Stockholder Litigation, C.A. No. 11775VCL, at *5 (Del. Ch. Dec. 21, 2015) (Hon. J. Travis Laster, Vice Chancellor, ruling orally on cross motions for summary judgment).

136 Frechter v. Zier, C.A. No. CV 12038-VCG, 2017 WL 345142, at *34 (Del. Ch. Jan. 24, 2017).

137 The distinction between property rules and liability rules is one of the foundational concepts in private law. See Guido Calabresi \& A. Douglas Melamed, Property Rules, Liability Rules, and Inalienability: One View of the Cathedral, 85 HARV. L. REV. 1089, 1092 (1972). 
shareholders, whereby the board could violate those rights and simply pay damages. Suppose, for example, the board (usually correctly) concluded that the annual meeting was a waste of money because, as is usually the case, there were no competing candidates for the board positions up for election. ${ }^{138}$ It is true, that the election of directors at annual meetings may well not justify their cost. Yet directors could not decide to commit an "efficient breach" of the company's voting agreement and pay damages; in that case, an injunction (property rule) would protect the shareholders' voting rights. This injunctive protection is an attribute of property (hence the term property rule) rather than contract. ${ }^{139}$

The proprietary nature of voting interests is further illustrated by appraisal rights, which traditionally (and still for the most part) attach to voting interests. Appraisal rights were part of the legal adaptation necessary to remove unanimity requirements from corporate law approval processes. In other words, the emergence of appraisal rights were the result of a quid pro quo; in exchange, corporate law moved away from a unanimous consent rule toward a majority voting rule. ${ }^{140}$ The idea was that appraisal rights offered shareholders the fair value of their shares in exchange for yielding the right to veto a transaction that deprived them of their property. ${ }^{141} \mathrm{It}$ follows, then, that appraisal rights in transactions generally

138 The default rule is that directors are elected by a plurality of the votes, so when there are only as many candidates as there are board positions the candidates are certain to be elected. See Lee Harris, The Politics of Shareholder Voting, 86 N.Y.U. L. REV. 1761, 1788 n.133 (2011).

139 Contract rights can, of course, be protected by property rules as well (usually by injunctions). However, the general prerequisite to injunctive relief in contract is that damages would be inadequate, whereas land is presumed unique and requires no such showing. See, e.g., 42 AM. JUR. 2D Injunctions $\S 116$, Westlaw (database updated Feb. 2020).

140 Michael Bradley \& Michael Rosenzweig, Defensive Stock Repurchases and the Appraisal Remedy, 96 YALE L.J. 322, 331 (1986).

141 See, e.g., 12B William Meade Fletcher et Al., Fletcher CyClopeDIA OF THE LAW OF PRIVATE CoRPorations § 5906.10 (perm. ed., rev. vol. 1990) ("The purpose of [appraisal] statutes is to protect the property rights of dissenting shareholders from actions by majority shareholders which alter the character of their investment."). 
follow voting rights, although not perfectly. ${ }^{142}$ Other interests in the corporation do not benefit from appraisal rights, because they arise from contract interests rather than property interests.

Shares are also unique among claims on the corporation in that they cannot be issued without first having been authorized in a public filing. ${ }^{143}$ Corporations are formed by a charter issued by the state in which the total number of authorized shares is required to be publicly disclosed. ${ }^{144}$ In contrast, contracts do not require a public filing or public notice for their creation. Thus, the other constituents in the corporation have no requirement to publicly disclose the total number of authorized interests they might have in the corporation. Stock is the only claim whose interests can only be created by a public filing.

This requirement of that the corporate charter be publicly filed to provide notice to third parties is a feature of property law, not contract law. ${ }^{145}$ The requirement of filing is in part designed to provide notice to third parties of shareholders' in rem rights, or rights "good against the world," which are characteristic of property interests, not contract rights. ${ }^{146}$ Relatedly, in case of conflict between the corporation's articles of incorporation and bylaws, the charter will prevail even if the bylaws were entered into after the charter. ${ }^{147}$ This illustrates

142 See Melvin Aron Eisenberg, The Modernization of Corporate Law: An Essay for Bill Cary, 37 U. MIAMI L. REV. 187, 194 (1983) (noting that appraisal rights generally follow voting rights, but not always).

143 Security interests on corporate property are typically filed as well, but security interests are property interests in an important sense. See, e.g., Thomas W. Merrill \& Henry E. Smith, The Property/Contract Interface, 101 CoLUM. L. REV. 773, 834-35 (2001) (explaining how security interests have aspects of both property and contract).

144 See supra note 125 and accompanying text.

145 See Henry E. Smith, The Persistence of System in Property Law, 163 U. PA. L. REV. 2055, 2067-68 (2015) (describing the public recording system as one of the "aspects of the property system most closely associated with its architecture" and the in rem nature of its public notice function).

146 A right in rem is a right in respect of a thing that binds the whole world, as opposed to a right in personam that binds only specific individuals. See J.E. Penner, The IdeA of Property in LAW 23, 80 (1997).

147 Del. CoDE ANN. tit. 8, § 109(b) (2019) ("The bylaws may contain any provision, not inconsistent with law or with the certificate of incorporation, 
the primacy of the property-like aspects of the articles (which are publicly filed for notice to third parties) over the more-contract-like bylaws (which are generally not filed). All of this is alien to contract law, where the latter agreement (the modification) would prevail in case of conflict.

A factor related to the public filing requirement is the exclusivity of the law that applies to the "internal affairs" of corporations. Corporations are, for the most part, governed in their internal affairs exclusively by the law of one state, the state in which the corporation was chartered. ${ }^{148}$ This is a puzzling doctrine from the perspective of the nexus of contracts theory, because the contractarian approach does not draw a sharp line between stock and other claims on the corporation. ${ }^{149}$ The most common rationale given for this rule is that it is necessary to protect the corporation from inconsistent and potentially conflicting requirements of various states' laws. ${ }^{150}$ However, there are reasons to believe that the possibility of inconsistent judgments is neither the best nor the only explanation for the internal affairs rule. ${ }^{151}$ There is also a risk of opportunism when the residence of a shareholder could affect the rights of that shareholder's claim on the corporation, particularly given the easy mobility of shares. ${ }^{152}$

The problems that arise when the personal attributes of shareholders are entangled with the governance of the

relating to the business of the corporation, the conduct of its affairs, and its rights or powers or the rights or powers of its stockholders, directors, officers or employees.").

148 See VantagePoint Venture Partners 1996 v. Examen, Inc., 871 A.2d 1108, 1115 (Del. 2005).

149 See Vincent S.J. Buccola, Opportunism and Internal Affairs, 93 Tul. L. REV. 339, 341 (2018).

150 See, e.g., Edgar v. MITE Corp., 457 U.S. 624, 645-46 (1982) (describing the internal affairs doctrine as necessary to prevent a situation where "a corporation could be faced with conflicting demands"); VantagePoint Venture Partners 1996 v. Examen, Inc., 871 A.2d 1108, 1112-13 (Del. 2005) (reasoning that the internal affairs doctrine emerged "in order to prevent corporations from being subjected to inconsistent legal standards").

151 See generally Buccola, supra note 149, at 348-59 (arguing that the most common rationales for the internal affairs doctrine, including the risk of inconsistency, are weaker than is commonly assumed).

152 See id. at 343. 
corporation are further justifications for the "in rem-ifying" function of the corporation. The exclusivity of one state's law over a corporation's internal affairs is also characteristic of property, rather than contract. Most property is governed by a "situs" conflict of law rule that provides the location of the property is the exclusive law applicable to it. ${ }^{153}$ Because the corporation itself as a legal entity (as opposed to the business) has no physical presence anywhere, its situs is its state of incorporation. This conflict of law rule is very similar to the situs rule applied in the property context, a rule that has remained resilient in the face of the "conflicts revolution." 154 This prevents the untenable situation that would occur if the legal attributes of the corporation shifted every time shares (or shareholders) moved across state lines. ${ }^{155}$

An important point is that the internal affairs doctrine relates to particular rights in the corporation, not to particular classes of actors. Shareholders can make contracts under the law of states other than the state of incorporation, and even outside of contract, the internal affairs doctrine is not applied to all relations shareholders have with the corporation. Securities law, for example, is widely considered to fall outside of the internal affairs doctrine. ${ }^{156}$ Thus, shares, unlike other claims on the corporation, have a property-like conflict of laws rule applied to them, with one state mandatorily governing those "internal" to the corporation.

Moreover, the way in which one acquires shareholder rights in a corporation is subject to a property-like rule, rather than a contract-like one. One acquires the rights of a shareholder merely by purchasing shares, rather than by agreeing to contractual terms. This is how rights are acquired in

153 See James Y. Stern, Property, Exclusivity, and Jurisdiction, 100 VA. L. REV. 111, 113 (2014).

154 See id. at 112-16.

155 This problem supports the need for in rem-ification whether the problem is conceived in terms of inconsistent judgments from having the law of multiple jurisdictions apply, as the traditional account of the internal affairs doctrines suggests, or the opportunism of shares flowing to jurisdictions where holdup is facilitated, as Vincent Buccola argues. See Buccola, supra note 149 , at 385 .

156 See Lipton, supra note 106, at 596-98. 
property, but not generally how rights are obtained in contract. Rights in contracts, in contrast, are acquired by manifesting assent to the terms of a bargain. An original contracting party often can assign contract rights to an assignee, but the assignor remains a party to the contract, absent a novation among all the parties. In contrast, once shares are transferred, with no contractual agreement by anyone, the assignor no longer retains any rights or duties, as when property is sold. Although this factor is not decisive, it too points toward shares being construed as a property interest.

Finally, the limited liability of corporations is often seen as a property-like right, in that it is good against the world and does not rely on contract. But there is a deeper sense in which the doctrine of limited liability itself is incoherent in a contractual context. Why is limited liability significant if shares are merely contractual claims on the corporation? Contracting parties do not generally insure their contractual counterparties for insolvency, so why would limited liability protection be needed or significant? There is no doctrine of limited liability for lenders, although their liability is generally limited. Principals have liability for actions taken by agents on their behalf, but if managers are agents in the nexus of contracts model they could only be agents for the "nexus," not the shareholders, as their actions do not bind the shareholders to contracts with third parties. The very existence of a limited liability doctrine implies that contract does not adequately capture the shareholder-corporation relationship.

\section{Summary}

This Part has laid out the case that the pure contractarian perspective on the legal institution of the corporation is fatal to the approach as a theory of corporate law. The contractarian theory cannot say what relationships are inside or outside the firm, and could even be thought of as a theory of why there are no firms. ${ }^{157}$ That is, the nexus of contracts approach suffers from the inability to clearly demarcate the boundaries of

157 Eisenberg, supra note 1, at 832. This very perspective was developed in Gulati's seminal Article. See Gulati et al., supra note 11, at 947. 
the firm. ${ }^{158}$ For legal purposes, the boundary problem is best solved by introducing ownership interests into the nexus of contracts.

Yet the search for ownership interests is not necessarily a search for "owners," at least in the usual fee simple sense. The traditional approach, which views shareholders as "the owners" of the corporation, oversimplifies in the other direction. The reality is more nuanced than shareholders exclusively holding ownership rights the way other claimants exclusively have contract rights. In general, no single class of stock is fully property or fully contract. Most equity interests will have a mix of property and contract interests. In general, common stock will have more property attributes than preferred stock, but not completely so and not in every case.

Thus, a framework is needed to determine which claims on the corporation constitute ownership interests and which claims on the corporation constitute contract interests. This is why the property theory of the firm, developed in the next Part, offers a way forward in understanding the legal nature of the corporation and classifying the complex set of contract and property relationships that exist in a corporation.

\section{BUILDING A PROPERTY THEORY OF CORPORATE LAW}

The previous Part outlined the limits of explaining corporate law in terms of contract law. This Part makes the affirmative case for a property theory of corporate law based on property theory. Section III.A proposes thinking of the corporation as an ownership structure. Section III.B examines corporate law through the lens of property theory's "right to exclude," arguing that corporate law strongly resembles property law. Section III.C builds the property theory from the ground up. It provides an explanation as to what portions of corporate law are property and which parts are contract. The dividing line turns on what can be recreated from contract. It further

158 Even treatments sympathetic to the contractarian approach identify this weakness, often with tepid pushback. See Ulen, supra note 33, at 321. 
integrates the burgeoning literature that has recognized certain property aspects of corporate law. Section III.D establishes the theoretical connection between ownership rights and fiduciary duties.

\section{A. The Corporation as an Ownership Structure}

If the corporation is not a nexus of contracts, what is it? It is clear that the corporation serves an important legal function separate and apart from the function of the "firm" as described in the law and economics movement. This Article argues that the corporation is best conceived of as an ownership structure: a device for converting disorganized jumbles of in personam relationships into tidy packages of in rem rights called "shares," which can then be divided and sold stripped of any in personam entanglements. The attributes of the stock inure to and are binding on those who acquire it after transfer, without the need for assignment or assumption agreements, and that is the core property aspect of the corporation as a legal institution. ${ }^{159}$

The key transformation effected by the corporation, therefore, far from being a transmutation from property into contract, is actually in the opposite direction: the transformation of in personam rights into in rem rights. There are two sides to the in rem nature of stock. One is that successors to the stock acquire rights good against the world (limited liability and the like). This in rem feature of share ownership is one of the important property features of the corporation that scholars have previously noted. ${ }^{160}$ The other side, far less understood, is that successors to the stock inherit the limitations of

159 The legal entity also facilitates the transfer of the underlying contract interests held by the corporation as a "bundle," which provides for transferability for the original owner (free from counterparty holdup problems) as well as protection of counterparties against the opportunistic transfer of contracts by the owner (because they must be transferred as a bundle). See Kenneth Ayotte \& Henry Hansmann, Legal Entities as Transferable Bundles of Contracts, 111 MicH. L. REV. 715, 717-18 (2013). Ayotte and Hansmann adopt a pure "nexus of contracts" perspective, and still recognize the unique legal value of the entity in encapsulating contract rights within a structure that is property-like. See id. at 725 .

160 See Joo, supra note 1, at 810. 
share ownership, just as those who acquire property subject to a servitude. This is also an aspect of the in rem relationship, although one not often appreciated, because servitudes are themselves in rem in a sense. ${ }^{161}$ Both sides of this in rem-ification of corporate stock apply to successor owners of the stock without any in personam agreement. That is what makes freely tradeable public corporations possible.

The corporation as an ownership structure is most clearly seen by examining the alternative arrangement. The alternative to a corporation is an individual or multiple individuals owning a business's assets jointly and making contracts jointly as a group. However, as discussed in Section III.C below, many important property-like features of the corporation could not be replicated by contractual agreements among coowners. Such an arrangement would imply a messy web of proprietary and non-proprietary relationships among many different co-owners of property. Thus, the corporation serves as a form of ownership that bundles together messy aggregations of rights into a tidy, divisible, transferable unit of ownership in the form of shares. By converting contract rights into property rights, the corporation gives personam rights an in rem character that facilitates capital formation. ${ }^{162}$

The fact that the corporation can be seen as an ownership structure - a distinct form of property ownership-explains why calling shareholders the "owners" of the corporation is

161 Glen O. Robinson, Personal Property Servitudes, 71 U. CHI. L. REV. 1449,1467 (2004) ("[I]t is in the nature of property servitudes that they create in rem obligations binding on persons who otherwise have no relationship to the creator of the obligation.").

162 This view is largely consistent with Amnon Lehavi's conception of the corporation as a "nexus of property" or a "property microcosm" in which "rights and duties can be structured so as to have an in rem effect." AMNON Lehavi, The Construction of Property: Norms, Institutions, ChalLENGES 196 (2013). One key difference between Lehavi's approach and that taken in this Article is that Lehavi distances himself from the "right to exclude" as the "essential" property trait in the corporation, whereas this Article builds its analysis largely on that property characteristic. See id. at 202. Specifically, Lehavi argues that the right to exclude "does not seem to be at the core of the business corporation." Id. The two analyses are completely consistent, however, in emphasizing the in rem function of the corporate entity. 
unwieldy; it does not mesh well with the reality of owning corporate shares. The corporation is not owned by the shareholders; it is only an organizational tool that allows shareholders to impersonally own business assets. Thinking of other forms of ownership, one does not generally talk of "owning" a fee simple or "owning" a tenancy in common. One talks about holding property in fee simple or in a tenancy in common. Similarly, one holds the business assets of a corporation in shares. In this view, the corporation is another form of ownership, one that is specialized for the task of allowing for wide ownership and free transferability of ownership shares.

The idea of the corporation as an ownership structure resonates with existing property theory across the spectrum. Even Honoré, who, as noted above, is often cited as standing against the idea of ownership interests in corporations, described them as a form of "split ownership." 163 But the idea of a corporation as an ownership structure based in property theory requires a theoretical foundation. The following Sections lay that foundation. The first step is to establish the set of rights within a property framework that form the foundation of ownership interests within the corporation. The next Section demonstrates that the property foundation rests on the residual, uncontracted for voting rights held by common shareholders-what this Article terms the "non-excludable right to exclude." The next step is to establish the boundaries of those property interests relative to the contractual claims on the corporation.

\section{B. Property Theory, the Right to Exclude, and Corporate Law}

To establish that the corporation has ownership interests, it is first necessary to determine what constitutes "property." There are many approaches to defining property, probably the

163 See Honoré, supra note 69, at 142 ("Secondly, splitting [ownership] may serve the purpose of specialization, by separating management from the enjoyment of income and/or disposition of the capital; the beneficiary obtains the advantage of expert management of the property but also runs some risk. In this second class fall such devices as trusts . . . and incorporated companies."). 
most widely accepted of which is the "bundle" metaphor discussed above. ${ }^{164}$ Importantly, however, the more recent "new essentialism" perspective argues that all mainstream approaches recognize that it is the right to exclude that has long been "at the center" of the definition of property. ${ }^{165}$ Indeed, one prominent commentator argues that the right to exclude is the very definition of property. ${ }^{166}$ Although there are critics of the traditional view that the right to exclude is the foundational sine qua non of property, even those critics generally agree that the right to exclude is among the most important aspects of property. ${ }^{167}$ This subpart develops the argument that the right to exclude provides the clearest lens to observe the property interests represented by common stock.

In a corporation, as in any organization, many actors hold what might be thought of as a right to exclude. The board of directors has the right to exclude by hiring and firing managers. Managers have the right to exclude by hiring and firing employees. Even lower level employees often have the right to exclude; a security guard or a store manager has the right to exclude people from corporate property, within limits. Indeed, those employees even have the right to exclude shareholders from their physical presence on corporate premises and from using corporate assets. Yet shareholders individually and directly cannot exclude anyone from the corporation. Thus, from a day-to-day perspective, shareholders have little claim on the right to exclude in the corporation. This is probably why the right to exclude has not been widely recognized as a right of shareholders.

164 See supra notes 160-62 and accompanying text.

165 Jonathan Klick \& Gideon Parchomovsky, The Value of the Right to Exclude: An Empirical Assessment, 165 U. PA. L. REV. 917, 920 (2017).

166 Thomas W. Merrill, Property and the Right to Exclude, 77 NEB. L. REV. 730, 754 (1998) ("[P]roperty means the right to exclude others from valued resources, no more and no less."). But see Gregory S. Alexander, The Complex Core of Property, 94 CoRNELL L. REV. 1063, 1070 (2009) (arguing that the "right to exclude" is not the sole boundary line of property).

167 See Klick \& Parchomovsky, supra note 165, at 919-20 (noting that Honoré, who is prominently associated with the "bundle of rights" approach to property, also was thought to put the right to exclude near the forefront). 
But shareholders do have the most important right to exclude within the corporation. Indeed, they hold the right to directly or indirectly exclude all others through their voting rights. The right to exclude held by shareholders rests fundamentally on their right to elect and remove directors, who in turn wield all management powers within the corporation. This right not only allows shareholders to exclude those who manage the corporation (the directors), it is the one governance right that is singled out for protection from interference by the board or anyone else. ${ }^{168}$

The right to exclude held by shareholders is a unique right within the corporation, unlike the right to exclude held by every other class of corporate actors. Employees and managers of the corporation can be excluded by higher-level managers or by the board. Even directors can be excluded by a vote of the shareholders using the removal power, and this action can be taken without the consent of any board members. ${ }^{169}$ The voting shareholders, however, cannot be excluded from the corporation without their (individual or collective) consent. The shareholders' right to vote cannot be excluded because the corporation's common stock cannot be eliminated and its attendant voting rights cannot be taken away. ${ }^{170}$ Voting shareholders are the only class of claimants on the corporation who hold a right to exclude that cannot itself be excluded without some form of consent. Thus, shareholders' right to exclude is itself non-excludable. This "non-excludable right to exclude" is a unique right within the corporation and it is held by shareholders alone. The non-excludable right to exclude is the most important attribute of property ownership in an organization.

The point that common shares cannot be eliminated is an important one. As discussed in the previous Part, the corporation must retain at least one share with full voting power. Note that the requirement is for a share with full (or residual)

168 See supra note 134 and accompanying text.

169 See DeL. Code ANN. tit. 8, § 141(k) (2019).

170 Corporations can create non-voting common stock, but they must have a class of common stock with full voting rights. See supra notes 123 24 and accompanying text. Non-voting stock is discussed in Section V.D, infra. 
voting power, not necessarily residual economic interest (although the MBCA requires both ${ }^{171}$ ). This argument alone is insufficient to demonstrate the uniqueness of shareholders, however, because generally the board itself cannot be eliminated either, unless the corporation opts into close corporation status. The crucial difference between shareholder and director removal is that shareholders can eliminate particular members of the board without their (individual or collective) consent. Although shareholders can also be frozen out, they cannot be frozen out without (at least) a majority vote or other consent of the broader shareholder base.

Thus, the right to exclude, represented by voting rightsmore specifically, the non-excludable right to exclude-is the feature of corporate stock that most strongly supports its construction as an ownership interest. This does not mean that all voting constitutes a strong right of ownership. For example, preferred stock often has the right to vote on amendments that adversely affect the interests of the preferred. ${ }^{172}$ However, this is merely a veto right, not unlike the rights held by other contractual counterparties. This right is not construed as a right of ownership because it does not allow holders to elect or remove directors, ${ }^{173}$ and therefore it does not encompass the residual control right to exclude.

It is true that individual shareholders can sometimes be forced to sell their shares-for example, in freezeout mergers in which minority shareholders are cashed out. ${ }^{174}$ There are three important reasons why this does not make the right to exclude excludable. First, shareholders cannot be forced to give up their shares without the (at least majority) consent of the shares themselves. ${ }^{175}$ In the event that shares are frozen out without a vote (as in a short-form merger), shareholders have the right to be paid the fair value of their shares in

171 Model Bus. CorP. ACT $§ \S 6.01(b), 6.03(\mathrm{c})$ (AM. BAR Ass’n 2016).

172 See, e.g., Del. Code ANN. tit. 8, § 242(b)(2) (2019).

173 A closer case are provisions that allow preferred shareholders or even debt holders to vote for directors under certain contingencies, such as the nonpayment of dividends or interest.

174 See Zohar Goshen \& Assaf Hamdani, Corporate Control and Idiosyncratic Vision, 125 YALE L.J. 560, 611 (2016).

175 See id. at 612-13. 
appraisal. ${ }^{176}$ In contrast, directors can be removed at any time without their individual or collective consent, and without any compensation. ${ }^{177}$ Second, the mere fact that one can be forced to sell does not defeat property status; co-owners of property can be forced to sell too, so that does not make the right to exclude excludable. Third, the property theory does not protect shareholders, but rather the shares that represent their ownership interests. ${ }^{178}$ Shareholders may be forced to sell their shares, but the shares themselves must remain outstanding at all times. These features are unique among all the claims on the corporation.

The voting interest, therefore, is the key attribute that identifies property rights within the corporation. Perhaps the most instructive comparison in isolating the unique ownership interests in the corporation is to consider corporations that are unowned-specifically, nonprofit corporations, which have no owners. ${ }^{179}$ In examining the role of formal control, the leading theorist on business ownership, Henry Hansmann, examined in his classic work the case of a widely held public corporation with little shareholder control. ${ }^{180}$ He classified this as an "investor-owned" firm. ${ }^{181} \mathrm{He}$ asked what difference it would make if we took away the formal voting rights of shareholders and replaced them with formal voting rights that were ineffective to control by assumption. ${ }^{182}$ The conclusion is that the resulting entity, although engaged in business, would be essentially a nonprofit-albeit one with shareholders as

176 See George S. Geis, An Appraisal Puzzle, 105 Nw. U. L. REV. 1635, 1641-42, 1648 (2011).

177 See Del. Code ANN. tit. 8, § 141(k) (2019).

178 This point is a subtle but important one. If the property right protected the interests of shareholders as individuals, then the board would have a duty to obey the majority will, even if it harms the minority. This is not the case, however, as fiduciary duties of the board attach to the minority interests as well.

179 See Henry Hansmann, The OWNERship OF EnTERPRISE 7 (1996) (describing nonprofit firms as those that "have no owners at all").

180 See id. at 1-3.

181 Id.

182 Id. at 61. 
beneficiaries. ${ }^{183}$ The firm would not have owners. Thus, formal voting control is necessary for ownership, and economic residual is not a sufficient standalone basis to find ownership.

One might ask how voting power can be the marker for ownership, and yet the nonprofit be unowned. After all, nonprofit corporations have those who exercise voting power too. Although Hansmann does not directly address this question, the key to resolving the puzzle is the fact that voting power cannot be sold by those holding it in a nonprofit. ${ }^{184}$ The right to sell voting power is an economic residual right. The rights of shares are often thought of as the right to vote and the right to sell, but just as fundamental is the right to sell the vote. This differentiates share voting from the authority of the board. The board can appoint new members to its ranks, or even its own replacements for a time, but cannot sell that right. Shareholders can sell that right, and as a result, there are no voting rights in the corporation that do not also constitute, at least in part, residual economic rights.

This Section has attempted to bridge the theoretical disjunction between property law and corporate law to show that there are property aspects in corporate law. Corporate law scholarship frequently addresses what corporations are, but addresses far less frequently what property is. The failure to engage seriously with property theory bears much of the blame for the contractarian excesses in corporate law literature. This Part has attempted to use property theory to shed light on the property interests in the corporation. Although this Section identified the right to exclude as the strongest marker for property, even those who do not subscribe to

183 Id. (explaining that the result of removing the votes "would be a firm that is formally nonprofit"). Although it perhaps seems incongruous to think of a business firm without voting rights as a nonprofit, as Professor Hansmann points out nonprofits are not prohibited from earning profits. Id. at 228. Rather, "the critical characteristic of a nonprofit firm is that it is barred from distributing any profits it earns to persons who exercise control over the firm." Id. In this context, voting rights are the "control."

184 See Usha Rodrigues, Entity and Identity, 60 EMORY L.J. 1257, 126768 (2011) (explaining that participants in non-profits cannot sell their interests, thus taking away the "market for corporate control" that exists with for-profit corporations). 
"exclusion theory" also consider at least some corporations and other business organizations to constitute property"governance property." 185 Indeed, governance property is thought of as a multiple owner property, ${ }^{186}$ which closely parallels the argument that the corporation is an ownership structure.

\section{The Property-Contract Borderline: Replicability of Corporate Law}

The previous Section provided a foundation for the existence of property rights in corporate law. It did not, however, delineate the breadth and depth of these property rights versus contract rights. The breadth issue addresses a boundary question: which rights are property rights and which are contract rights? As mentioned previously, shareholders often hold some proprietary claims and some contractual claims, and classifying those claims affects their treatment under the law. The depth issue addresses what type of ownership interests shareholders have. Are those ownership interests legal, equitable, or both, and do they attach to the corporation itself or to the assets of the corporation?

\section{The Breadth of Property Rights}

This Section builds the property theory from the ground up using a legal version of Coase's Theory of the Firm argument. Coase asked why the economic institution of the firm exists, as opposed to simply allowing market transactions to

185 See Alexander, supra note 79, at 1856-57. It is unclear why Alexander mentions only close corporations and not public corporations.

186 See id. at 1856. Alexander argues that the "exclusion theory" such as that associated with Merrill and Smith ignores what happens among property stakeholders-what he calls "governance property." See id. at 1854-55. As this Article uses the concept of exclusion to draw property lines in the corporation, the use of governance property may seem to be in tension. However, Smith responds, relevantly for this Article, that governance property is similar to what Merrill and Smith refer to as "entity property," including corporations. See Smith, supra note 145, at 2073-74 n.71. Thus, it may be said that the exclusion approach does not preclude consideration of governance property principles. 
coordinate all economic activity. ${ }^{187}$ Coase's theory addressed why economic activity is organized in firms, but not why economic activity is organized in corporations (or other legal entities). Although Coase referenced the legal concepts of employees and independent contractors as the basis of a firm, he did not ask why the firm as a legal entity exists. Indeed, the concept of a Coasean firm includes a sole proprietorship with employees, because the key aspect of a firm in Coase's account is the hierarchy relation, not the organizational form. ${ }^{188}$

This Part asks why the legal institution of the corporation exists, and identifies the inability to replicate corporate law features through contract as the reason. The inability to replicate corporate law features through contract is a result of at least two different tensions. One is the practical impossibility of providing for the necessary detail to supply such a contractual solution, as in the case of defining fiduciary duties. The other is the practical impossibility of contracting with all potential claimants on the corporation or transferees of shares, as in the case of the in rem features of the corporation. The core property-like attributes of the corporation involve one of these two impediments to replication by contract, and therefore must arise from another source, such as a property interest.

The starting place for this analysis is to note that in practice, a business of any significant scale is organized in entity form. Why do parties not simply own business assets directly and use detailed contracts to regulate co-ownership and governance? Answering this question requires a legal adaption of Coase's foundational question. Why do businesses operate in corporate form (or other entity form), and what's the alternative? There are two answers to this question. The first is the fairly trivial aspect of the convenience of a legal personality (limited liability, and so forth). But even this answer begs the second question: why not just reproduce those mundane corporate features within the boundaries of contract law?

The answer to this question draws upon a growing literature that recognizes the fact that many aspects of corporate

187 Coase, supra note 19 , at 390.

188 See supra notes 25-29 and accompanying text. 
(and other organizational) law could not be replicated by contract, and therefore business institutions grow out of other bodies of law, such as property law. This approach-which this Part calls the "replicability approach"-was pioneered by Hansmann and Kraakman in their classic article, The Essential Role of Organizational Law. ${ }^{189}$ In that work, Hansmann and Kraakman examine the unique role organizational law plays by searching for corporate law features that contracting alone could not replicate. ${ }^{190}$ Hansmann and Kraakman reasoned that those features not capable of being replicated by contract law often arise from property law. ${ }^{191}$

Of the many attributes of corporate law, Hansmann and Kraakman identify the protection of the assets of the corporation from the creditors of its shareholder owners-what they call "affirmative asset partitioning" - as the essential and unique feature of organizational law. ${ }^{192}$ Affirmative asset partitioning requires creditors of the shareholders to stand in line behind the creditors of the entity, making it possible for lenders to extend credit to the entity without worrying about the in personam contractual relationships of the owners. ${ }^{193}$

Asset partitioning is an important part of what this Article colloquially refers to as the "in rem-ification" function of the corporation. Affirmative asset partitioning uses the corporation as a vehicle for stripping the in personam features from business assets and converting them into in rem property claims. Importantly, Hansmann and Kraakman see asset partitioning as "essential" to organizational law in the sense that contract could not reproduce the same effect. ${ }^{194}$ The contribution of Hansmann and Kraakman demonstrated not only that property is an essential part of corporate law, but that there

189 Henry Hansmann \& Reinier Kraakman, The Essential Role of Organizational Law, 110 YALE L.J. 387 (2000).

190 Id. at 390.

191 Id.

192 Id

193 Id.

194 Id. 
is an analytical technique for separating contract from property. ${ }^{195}$

Hansmann and Kraakman advanced the understanding of organizational law by identifying affirmative asset partitioning as an important feature of corporate law. However, Hansmann and Kraakman failed to extend their logic to reveal that asset partitioning is not the only unique organizational feature (and, therefore, property feature) of corporate law; there are other aspects of organizational law that cannot be replicated by contract. Indeed, it is Hansmann and Kraakman's approach to identifying the distinctive aspects of organizational law that leads to the broader finding of more property law features in corporate law than their article explicitly recognizes.

The most important feature of corporate law that contract law cannot replicate emerges directly from the contractarian account itself-fiduciary duties. Recall that the contractarian rationale for fiduciary duties is that transaction costs prohibit parties from writing a contract that would govern how management should behave in each possible contingency. ${ }^{196}$ Yet, viewed through the replicability analysis, the inability to achieve the corporate law result through contract is itself evidence that contracting is an inadequate means to replicate fiduciary duties.

Conceivably, parties could enter into a contract that expressly established fiduciary duties, though the extent to which a court would respect such a contractual term is unclear. Even under corporate law, where fiduciary duties already exist (by default and mandatorily), it is far from clear

195 It is important to note that it is not inevitable that property law should have turned out this way, so corporate law could have been otherwise. This is a point that has been made about the Hansmann and Kraakman argument and applies here as well. See Paul G. Mahoney, Contract or Concession? An Essay on the History of Corporate Law, 34 GA. L. REV. 873, 878 (2000) (arguing that property law and contract law could have evolved the type of asset partitioning found in organizational law, had historical forces not aligned against that evolution).

196 See supra Section II.B. 
that contract can create additional ones. ${ }^{197}$ But even if it could, writing a contract that provides for fiduciary duties does not make fiduciary duties contractual. Moreover, the charters of companies do not explicitly provide for fiduciary duties; to the extent they address the subject, they cut back on them. ${ }^{198}$

Of course, parties could, in theory, replace fiduciary duties by writing a contract that would restrain managers by covering every possible contingency. Indeed, in theory parties could replicate asset partitioning or even limited liability, although it would be difficult vis-à-vis tort creditors. ${ }^{199}$ Doing so would require contracting with every potential creditor of the shareholders (replicating affirmative asset partitioning) and/or every potential victim of a tort perpetrated by the corporation (replicating limited liability, or even tort law itself).

But the fact that fiduciary duties, limited liability, tort law, or even property law itself could conceivably be replicated by contracts with everyone in the world does not mean those areas of law are contract. Whether provisions could be replicated by contract is a matter of degree that depends on the transaction costs involved. In all of these cases, tort, property, affirmative asset partitioning, and fiduciary duties-transaction costs prohibit contractual replication.

Ultimately, the replicability argument from Hansmann and Kraakman undermines contractarian theory as an account of the rights of common stock. Even a simple analysis shows that the nexus of contracts theory contradicts the replicability approach. According to contractarian theory, if coowners of business assets replicated all of the features of the corporation through contracts, then they would hold only contractual claims. But what would have happened to their property interest in the business property? There is no set of contracts that could have turned those property rights into contract rights. But without a corporation, there would be no owner of the property. This creates a contradiction. As a

197 See, e.g., Jesse M. Fried \& Mira Ganor, Agency Costs of Venture Capitalist Control in Startups, 81 N.Y.U. L. REV. 967, 1014 (2006) (explaining that enlarging fiduciary duties in the corporation is thought to be problematic because of the mandatory nature of fiduciary duties).

198 See, e.g., DEL. CodE ANN. tit. 8, § 102(b)(7) (2019).

199 See Velasco, supra note 8, at 920-21. 
result, the contractarian approach requires that the corporation $i s$ a set of contracts but could not be replicated by a set of contracts, which creates a serious tension.

Having shown that transaction costs prohibit a contractarian perspective on stock, it is appropriate to show how property law resolves these issues. Property law deals with the transaction costs involved in creating agreements that will bind unknown (and even unknowable) counterparties-in rem obligations. ${ }^{200}$ The in rem aspects of private law are quintessential property mechanisms, operating differently from the in personam mechanisms of contract law. The next few paragraphs provide several examples of how property mechanisms in corporate law enable the in rem features necessary for a widely held corporation.

The governance of the corporation could not be replicated by contract, even when supplemented by ordinary property law. Business owners could hold the business's assets in a cotenancy form, but the rights that cotenants have (to use and possess the whole property, to transfer their interests, and to force a partition) would make this problematic. ${ }^{201}$ The parties could attempt to contract around this, but those contracts would likely be unenforceable restraints on alienation and the contractual remedies available would be inadequate. ${ }^{202}$ To make the corporation work a purchaser would need to agree not to exercise normal property rights. But agreements much less intrusive than that have been held to violate the rule against perpetuities and constitute an impermissible restriction on the right of partition. ${ }^{203}$ Thus, the property features of the corporation provide the solution.

Transferability of shares, one of the core attributes of the corporation, requires the in rem features of property. This is because the special restrictions described above would also need to be enforceable against transferees. In this regard, a

200 See supra Section II.C.2.

201 Morgan Ricks, Organizational Law as Commitment Device, 70 VAND. L. REV. 1303, 1321 (2017).

$202 I d$.

203 See, e.g., Roberts v. Jones, 30 N.E.2d 392, 394 (Mass. 1940) (holding that a perpetual restriction on partition and alienation violated public policy). 
public company in which anyone can buy shares has a necessarily in rem character that is not replicable by contract. Share ownership is open to an indefinite and diffuse class of persons, and it is thus not feasible to contract with all those who might purchase the shares. Property has a means of dealing with this-servitudes that "run with the land." The fact that transferees of corporate stock are subject to certain restrictions without entering into any contractual agreement is similar to a servitude in property, which is an in rem right in the sense that it applies even to those with no relationship to the holder of the right. ${ }^{204}$ In other words, it "runs" with the asset even as to those who have no contractual relationship with the asset's owner, a characteristic of property. ${ }^{205}$ In a sense, this "transferability" argument is the general case underlying Hansmann and Kraakman's affirmative asset partitioning theory. ${ }^{206}$ It is the two-sided in rem feature of corporate law that is not replicable by contract, and these are the mandatory features of corporate law.

The connection between share transferability and property-like rules is illustrated by comparing unincorporated associations with corporations. Partnerships, for example, have greater contractual flexibility than corporations, ${ }^{207}$ notably in allowing for the curtailment or elimination of fiduciary duties in some jurisdictions. ${ }^{208}$ Additionally, the LLC, particularly in

204 Robinson, supra note 161, at 1467 ("[I]t is in the nature of property servitudes that they create in rem obligations binding on persons who otherwise have no relationship to the creator of the obligation.").

205 Henry Hansmann \& Reinier Kraakman, Property, Contract, and Verification: The Numerus Clausus Problem and the Divisibility of Rights, 31 J. LEGAL STUD. S373, S374 (2002) (noting that one of the most principal elements of property is that property rights can be enforced against transferees of an asset).

206 The affirmative asset partitioning concept protects assets from the creditors of the owners. See Hansmann \& Kraakman, supra note 189, at 390. But an equally important role of the concept is to protect the assets from a transferee. Indeed, a creditor of the owner is essentially just a special case of a transferee.

207 See, e.g., Anglo Am. Sec. Fund, L.P. v. S.R. Glob. Int'l Fund, L.P., 829 A.2d 143, 150-151 (Del. Ch. 2003).

208 See Scott Gordon Wheeler, Comment, LLC Fiduciaries: Where Has All the Good Faith Gone?, 59 U. KAN. L. REV. 1063, 1066-67 (2011). 
Delaware, is "primarily a creature of contract." 209 That is, Delaware's LLC statute expressly "give[s] maximum effect to the principle of freedom of contract" and allows parties to eliminate all fiduciary duties. ${ }^{210}$ Still, there is a residual property interest recognized even in the most contractual of entities. In other words, there is a spectrum of "propertyness" in business associations with public corporations on one end and LLCs and general partnerships near the other end. ${ }^{211}$

On this spectrum, an interesting pattern is that as the transferability of shares increases, mandatory rules as to fiduciary duties also tend to increase. First, partnerships and LLCs are the least transferable, and they have the fewest mandatory rules relating to fiduciary duties. ${ }^{212}$ Close corporations are in the middle, and they have more mandatory rules. ${ }^{213}$ Publicly held corporations generally have the most mandatory rules, and are the most readily transferable. ${ }^{214}$ This pattern supports the notion that the corporate form is designed to promote transferability of shares that would otherwise be infeasible in contract law.

However, even in Delaware, and even in the case of the LLC, there are limits to the "purely contractarian" perspective. ${ }^{215}$ Indeed, there is resistance to the idea that partners own partnerships or partnership assets. Partnership assets

209 In re Seneca Invs LLC, 970 A.2d 259, 261 (Del. Ch. 2008).

210 Del. Code AnN. tit. 6, § 17-1101(b)-(c) (2019).

211 Partnerships and LLCs should be characterized as "near" the end because it is of course possible to organize a business purely with contract by not using an entity at all.

212 See Wheeler, supra note 208, at 1066-67, 1069-76.

213 See Shannon Wells Stevenson, The Venture Capital Solution to the Problem of Close Corporation Shareholder Fiduciary Duties, 51 DukE L.J. 1139, 1142-44 (2001).

214 See Wheeler, supra note 208, at 1067-68. Other types of mandatory rules, however, are sometimes relaxed in the public company setting. An example is cumulative voting in California, which is required for private companies but not for public companies. See CAL. CoRP. CoDE $§ 708$ (West 2019) (requiring cumulative voting in general); CAL. CORP. CODE $\S 301.5$ (West 2019) (allowing "listed corporations" to eliminate cumulative voting).

215 See In re Carlisle Etcetera LLC, 114 A.3d 592, 605-06 (Del. Ch. 2015) ("[T] he purely contractarian view discounts core attributes of the LLC that only the sovereign can authorize, such as its separate legal existence, potentially perpetual life, and limited liability for its members.”). 
were formerly held by partners directly under the Uniform Partnership Act as a "tenancy in partnership." ${ }^{16}$ However, even under that older "aggregate" view of the partnership, partners did not retain the rights generally associated with being tenants in common, being limited by their equitable ownership. ${ }^{217}$ Thus, even in the most highly contractual setting, there is a property residue, and this property residue is directly related to the transferability of the interest at issue.

All of the features identified in this Section, such as the presence of fiduciary duties and transferability free from in personam entanglements have a few things in common. First, they could not be replicated by contract without prohibitive transaction costs. Second, and relatedly, they are themselves in rem rights that attach automatically to shares and follow the ownership of shares. Third, they are mandatory terms of corporate law that attach automatically to common shareholders' interests without explicit agreement. These commonalities are all property-like aspects of these rights of common shareholders.

The breadth of the property rights of the corporation, therefore, extend to the default corporate law rules applicable to the residual voting interest of the corporation (typically common stock). Customized rules, such as charter or bylaw provisions that deviate from the relevant default rules (to the extent such deviations are permitted), have the attributes of contract rights. This tentative borderline between default rules as property will be explored further below.

\section{The Depth of Property Rights}

The in rem theory outlined in the previous Section draws tentative lines around which interests in the corporation sound in property and which in contract. This Section addresses the depth of those property rights-in other words, what are they property rights in? As explained above,

216 See UNIF. P'ShIP ACT $§ 25$ (Unif. Law Comm'n 1914).

217 See generally Ricks, supra note 201, at 1327-42 (describing the "disgorgement feature," "the in rem feature," and the "title consolidation feature" as partnership limitations on the normal incidents of ownership as cotenants). 
shareholders do not hold the same type of property interests in corporate assets as a fee simple owner in the Blackstonian sense, ${ }^{218}$ or even the shared rights of a tenant in common. So, shareholders hold something different, something shallower than traditional ownership in property.

The notion that the corporation is a way of owning assets bumps immediately into the black letter law that the corporation, and not the shareholders, is the legal owner of corporate assets. ${ }^{219}$ Even the proponents of shareholder ownership often make the distinction between owning the corporation and owning its assets. ${ }^{220}$ This, however, relates to the legal ownership of those assets, which does not address the equitable interests in them. Indeed, the notion that shareholders hold an equitable ownership interest in the corporation's assets and that that ownership interest is the reason for the existence of fiduciary duties has percolated through Delaware and other courts for a century. ${ }^{221}$ The fact that corporate shareholding reflects an equitable interest in corporate assets is further reflected in the role of the Chancery Court-an equity court-as the corporate law court.

Thus, the corporation has legal ownership of its assets, and shareholders do not have fee simple interests in the corporation's assets as tenants in common. Although there are similarities between corporate ownership and tenancies in common, ${ }^{222}$ the property interests in the corporation's assets are

218 BLACKSTONE, supra note 104, at 2.

219 See, e.g., Purcel v. Wells, 236 F.2d 469, 472 (10th Cir. 1956) ("The corporation and not the stockholders is the legal owner of its property.").

220 See Velasco, supra note 8, at 908.

221 See 2 Arthur W. Machen, Jr., A Treatise on the Modern LaW of Corporations With Reference to Formation and Operation under GenERAL LAWS $§ 1399$ (1908) ("Furthermore, the relationship of directors to the corporation and those who are the real owners of its rights, property and assets, the stockholders, resembles in some respects that of agent to principal, of managing to dormant partner, and of trustee to beneficiary."); see also Cahall v. Lofland, 114 A. 224, 232 (Del Ch. 1921) ("One fundamental feature of the relationship is fidelity as to a trust, and that no advantage can be derived by a director by reason of his position.").

222 Danielle D’Onfro, Limited Liability Property, 39 CARdozo L. REV. 1365, 1380-81 (2018) (explaining how viewing equity holders as tenants in common clarifies the understanding of what they hold). 
equitable interests and not legal interests. That equitable ownership, and the decoupling of legal from equitable ownership, is an echo of the trust, from which our modern law of fiduciary duties emerges. This connection will be discussed in more detail in Section III.D below.

\section{The Boundary Question in Corporate Law}

Corporate law cannot exist without drawing boundaries, as the internal affairs doctrine attests. The property theory draws its boundaries at the property-contract borderline. This boundary is relevant even if one subscribes to the contractarian theory, because even if shares are contracts, corporate contracts are interpreted differently from other contracts. For example, even open-ended contracts generally do not imply fiduciary duties as corporate contracts do.

Thus, courts "do something different" in the case of corporate contracts. Even if one considers corporate law to be guided by special contract rules, courts need to know when they should apply these different rules. Where to draw the line will not be apparent in all cases. But the property rules described above-those that contract cannot replicate-are all considered "off-the-rack" defaults of corporate law. The default rules that attach to shares with residual control rights are the boundary line between corporate law and contract law. Thus, shareholders can simultaneously have both contract and property rights in the corporation.

\section{The New Literature on Property in the Corporation}

The analysis above builds on a growing literature exploring the property aspects of organizational law, pioneered by Hansmann and Kraakman. Although the nexus of contracts approach dominates the scholarly literature on corporate law, a different view exists in the scholarly literature on property law, where scholars often regard corporate law as deriving more from property than contract. ${ }^{223}$ Even within corporate

223 James Y. Stern, The Essential Structure of Property Law, 115 MicH. L. REV. 1167, 1201-02 (agreeing with Hansmann and Kraakman that 
law, however, a growing literature has identified various aspects of corporate law that contract cannot replicate, suggesting a property residue exists within corporate law. ${ }^{224}$ These approaches identify a "proprietary foundation" of corporate law on which the "contractarian superstructure is constructed." 225 Thus, the corporate law literature is moving toward property approaches to the corporation. ${ }^{226}$

The springboard for this new property literature on the corporation was Hansmann and Kraakman's pioneering article. Their work stimulated other work that identified other features of organizational law that couldn't be replicated by contract. In particular, Armour and Whincop have made important contributions by building upon Hansmann and Kraakman's piece. Whereas Hansmann and Kraakman focus on "affirmative asset partitioning" as the property law portion of corporate law, Armour and Whincop envision a broader role for property law in the corporate context. ${ }^{227}$ Armour and Whincop draw the line between the "proprietary foundations" of corporate law from its "contractarian superstructure" based on whether "the provisions in question could be replicated by private contract." ${ }^{228}$ Although Armour and Whincop stop short of recognizing the property features identified in this Article, their analysis provides important support for this emerging property view.

Similarly, a recent contribution by Morgan Ricks regards another important part of organizational law as "property relinquishment." 229 A complement to the asset partitioning

"organizational law is property law, not contract law" on the basis of the "mutual exclusivity" principle of property).

224 See, e.g., Hansmann \& Kraakman, supra note 189, at 393.

225 John Armour \& Michael J. Whincop, The Proprietary Foundations of Corporate Law, 27 OxFORD J. LEGAL STUD. 429, 449 (2007).

226 See LEHAVI, supra note 162, at 186 ("[C]orporate theory has gradually shifted from a contract-based analysis to one that investigates the role that property rights play in the structure of the firm. ...").

227 Armour \& Whincop, supra note 225, at 463 ("The range of rules thereby included [in the proprietary foundations of corporate law] is, we consider, significantly broader than the notion of 'affirmative asset partitioning' developed by Hansmann and Kraakman.”).

228 Id. at 449 n.79.

229 Ricks, supra note 201, at 1306. 
concept introduced by Hansmann and Kraakman, property relinquishment deals with the relations among co-owners themselves. ${ }^{230}$ And like asset partitioning, it cannot not be replicated through contract.231 One could argue that Professor Ricks, in his account of property relinquishment, describes a form of "property transmutation," not unlike what is discussed in this Article.

An even more recent scholarly analysis by Eldar and Verstein refines the Hansmann and Kraakman framework to identify the distinctive features of security interests as compared to business organizations. ${ }^{232}$ Security interests, like corporations, straddle the border between property and contract. Eldar and Verstein show that security interests cannot replicate the features of these entities, ${ }^{233}$ suggesting that the property nature of business associations is even more robust than that of security interests.

These contributions in the new property literature identify specific aspects of organizational law that join affirmative asset partitioning as features not replicable by contract. In a sense, these are all subcategories of the general point made in this Article, that organizational law in general, and corporate law in particular, is a device for "in rem-ifying" disparate assemblages of assets. The most important attributes of the corporation-limited liability, free transferability, perpetual life, and the managerial prerogative of its board of directors-are all parts of the in rem property nature of the corporation.

\section{The Property-Fiduciary Connection}

To this point, the analysis in this Article has sought to show the existence of property interests in the corporation and to begin to demarcate the boundaries between those property interests and contract interests. This Section shows that those property interests connect both directly and indirectly to the fiduciary duties of directors in the corporation. This

230 Id. at 1351.

231 Id. at 1309.

232 Ofer Eldar \& Andrew Verstein, The Enduring Distinction Between Business Entities and Security Interests, 92 S. CAL. L. REV. 213, 218 (2019). 233 Id. at 218, 270. 
connection sets the stage for Part IV, which shows that those property interests in the corporation are residual interests, but a different type of residual interest from those in the law and economics "residual claimant" analysis. Thus, the argument that spans this Section and Part IV is that fiduciary duties arise not from the fact that common shareholders typically hold the economic residual, but because they hold residual control.

As discussed above, the contractarian conception of the corporation struggles to account for fiduciary duties because such duties do not typically arise in contract and do not attach to other parties' discretionary decisions. ${ }^{234}$ In contrast to contracts, which generally do not give rise to fiduciary duties, there are two common contexts closely related to the corporate law setting where fiduciary obligations do traditionally arise - trusts and principal-agent relationships.

The literature on the theoretical underpinnings of fiduciary obligations is extensive, controversial, and spans various fiduciary contexts. ${ }^{235}$ One thing that unites this literature is the idea that one who deals with the property of another on behalf of the other assumes fiduciary duties. ${ }^{236}$ Thus, it follows directly that those who manage the corporation will have fiduciary duties if the interest held by shareholders is "property" as established above. Indeed, Gordon Smith, a leading scholar of fiduciary law sums up this connection succinctly: "the distinctive duty of loyalty that is imposed on fiduciary relationships is designed to protect the beneficiary's propertylike interest in critical resources." 237 Although most fiduciary scholars agree that property law concepts cannot provide a general account of fiduciary duties, most agree that dealing with property on behalf of another is sufficient to imply

234 See supra Section II.C.2.

235 Some of the more influential pieces include TAMAR Frankel, FidU. CIARY LAW (2011), Paul B. Miller, Justifying Fiduciary Duties, 58 MCGILL L.J. 969 (2013), and Smith, supra note 10.

236 See Smith, supra note 10, at 1403.

237 D. Gordon Smith, Firms and Fiduciaries, in ConTract, StATUs, AND Fiduciary LaW 293, 294 (Paul B. Miller \& Andrew S. Gold eds., 2016). 
fiduciary duties, ${ }^{238}$ which is the connection required for present purposes.

The property-fiduciary connection, as well as its complexities, is not unique to the corporate context. The analogy between the corporation and the trust has long been a part of the thinking about corporate law. In trust law, as in corporate law, there is a longstanding debate over whether the beneficiary of a trust has an in rem interest in the trust's property or merely an in personam claim against the trustee to perform the trustee's duties. ${ }^{239}$ But trusts themselves are generally defined as a fiduciary relationship to property, ${ }^{240}$ meaning that the trust analogy would not apply to a corporation viewed as a pure nexus of contracts. In any event, shareholders have more incidents of ownership than do trust beneficiaries, ${ }^{241}$ suggesting that the property-like attributes of a trust beneficiary's interest are equal if not greater in corporate shareholding.

The second broad area of law in which fiduciary duties appear is the agency context. Although writing in the law and economics tradition often describes directors as "agents," and although directors bear some similarity to agents, ${ }^{242}$ the duties they assume are not legally equivalent to those of an agent. ${ }^{243}$ The fact that directors act on behalf of shareholders,

238 Smith, supra note 10, at 1403-04 (explaining that "[l]awyers have long understood that one who deals with property on behalf of the beneficial owner of the property is subject to fiduciary duties," but that property cannot account for all fiduciary duties).

239 See, e.g., Helene S. Shapo Et AL., Bogert's The Law of Trusts AND TRustees $\S 183$, Westlaw (database updated June 2019).

240 See Restatement (ThiRd) OF TRusts § 2 (AM. LAw. Inst. 2003) (“A trust . . . is a fiduciary relationship with respect to property, arising from a manifestation of intention to create that relationship and subjecting the person who holds title to the property to duties to deal with it for the benefit of . . . one or more persons, at least one of whom is not the sole trustee.").

241 Velasco, supra note 8, at 907.

242 See Victor Brudney, Contract and Fiduciary Duty in Corporate Law, 38 B.C. L. REV. 595, 611 n.40 (1997). The Restatement (Third) of Agency commentary takes the position that directors are not agents. See RESTATEMENT (THIRD) OF AGENCY $§ 1.01 \mathrm{cmt}$. f(2) (AM. LAW INST. 2006).

243 See Brudney, supra note 242, at 611 . In a literal nexus of contracts model, however, managers really would be the agents of shareholders (and every other contractual claimant), in a sense. This is because they would be 
and with respect to assets in which shareholders have a property interest (albeit equitable and not legal) creates an analogy (albeit imperfect) to the fiduciary relationship of agency.

Thus, the trust and principal-agent relationships have several features in common with the corporation. Indeed, in a sense the corporate director's position is the primary place in which agency and trusts come together. And both of these are, at least in part, property-based relationships. The property aspect of corporate stock connects to the trust aspect of fiduciary duties. The agency aspect connects to the voting right as being the essential part of the property-fiduciary connection.

Moving from fiduciary theory to corporate law, the connection becomes clear, not just between property in general and fiduciary protections, but between voting rights specifically and fiduciary protections. The voting right is one that is singled out in Delaware law as receiving special protection from board incursion; attempts to interfere with the shareholder franchise triggers heightened scrutiny unlike other changes to shareholder rights. ${ }^{244}$ One of the strongest pieces of evidence for the direct connection of shareholder voting to fiduciary duties is the "cleansing" mechanisms for conflict of interest transactions under corporate codes. Whether under Delaware's Section $144^{245}$ or the Model Business Corporation Act's Subchapter F, ${ }^{246}$ conflict of interest transactions can be cleansed by the vote of disinterested shareholders. It is the

empowered to change the legal relations of the corporation. Under entity theory that does not make them agents of the shareholders because they are changing the legal relations of the corporation, not the shareholders. But under nexus theory, the corporation is a nexus of contracts, so to alter the corporation's legal relations is to alter the contractual rights shareholders hold in the corporation. That is inconsistent with the fact that shareholders have no contractual obligations qua shareholders to the corporation or anyone else, further establishing the importance of property to the fiduciary relation.

244 See Blasius Indus., Inc. v. Atlas Corp., 564 A.2d 651, 659 (Del. Ch. 1988).

245 See Del. Code AnN. tit. 8, § 144 (2019).

246 See Model Bus. Corp. ACt $§ 8.62$ (Am. BAR Ass’n 2016). 
voting shareholders who have the ability to sanitize fiduciary violations, and no others. ${ }^{247}$

The fact that this power to ratify conflicted transactions is given uniquely to the voting interests is significant because voting interests and economic interests may differ from one another, as is the case with dual-class structures or, in the extreme case, non-voting stock. ${ }^{248}$ Yet it is the voting interests that have the ability to cleanse conflict of interest transactions from fiduciary violations and avoid a reviewing court from applying a fairness analysis, not the economic interests of all stockholders generally (including non-voting stock). The fact that voting shares alone can cleanse a fiduciary violation strongly suggests that the highest priority fiduciary obligation is owed to the voting shares alone. ${ }^{249}$ The implications of these property-based relationships for fiduciary duties and the theory of the firm are elaborated in Part IV.

\section{PROPERTY VERSUS CONTRACT RESIDUAL CLAIMS AS EXPLANATIONS OF FIDUCIARY DUTIES}

The residual nature of common stock is foundational to both the nexus of contracts theory and to the property theory. Under the two accounts, however, the type of residual interest at issue is different. The contractarian model focuses on the residual economic interests of the common stock, and views the common stock's residual economic status as the driver of both fiduciary duties and voting rights. The property theory focuses on the residual control power common stockholders

247 Both the DGCL and the MBCA refer specifically to the shareholders "entitled to vote" as those relevant for the purpose of cleansing conflict of interest transactions. See tit. 8, § 144(a)(2) (referring to "the stockholders entitled to vote thereon”); MODEL Bus. CORP. ACT $§ 8.63$ (c)(ii) (defining the "qualified shares" that vote to cleanse a transaction as "all shares entitled to be voted with respect to the transaction" that meet certain requirements of disinterestedness).

248 See infra Section V.C.

249 Although one might ask how non-voting shares would be able to vote, such a mechanism is provided in Section 242 of the DGCL. See tit. $8, \S$ 242(b)(2) (providing for a required vote of a class of shares on certain amendments to the charter, even if the class is not otherwise allowed to vote). 
retain in the form of their voting rights and views those voting (ownership) interests as the driver of fiduciary duties. This Part describes the relevance of these two versions of residual interests and their implications.

\section{A. Revising Residual Claimant Analysis}

Part III examined the parts of corporate law that could not be replicated by contract as candidates for being the property interests in the corporation. This Part begins with the flip side of this argument, examining the important rights that can be replicated by contract. The most important right in this category is the economic residual right normally belonging to common stock. The economic residual can be replicated by contract without using stock, but in such cases produces dramatically different results in legal effect. The creation of economically equivalent rights with different legal treatment illustrates the point that fiduciary and voting rights come from residual control rights, not residual economic interests.

Consider, for example, an in-the-money warrant sold by the corporation to an investor. Such an investment replicates the economic interest of common stock without the voting interest. ${ }^{250}$ As a holder of a contractual right, the warrant holder will not have the benefit of fiduciary duties, ${ }^{251}$ even though the holder is a residual claimant in all relevant respects, identical to the case of common stock. This is an important point, because it shows that fiduciary duties do not necessarily follow

250 This is true only under certain quite restrictive conditions that differ substantially from real equity markets. See Velasco, supra note 8, at 917. However, the fact that the mechanism is not frequently used in practice only shows its possible inefficiency, not its theoretical equivalence to common stock ownership. See Fischer Black \& Myron Scholes, The Pricing of Options and Corporate Liabilities, 81 J. PoL. ECON. 637, 649-50 (1973) (explaining how option pricing theory can recharacterize debt as ownership of corporate assets and common stock as an option to acquire those assets by paying the debt).

251 See Feldman v. Cutaia, C.A. No. 1656-N, 2006 WL 920420, at *6 n.37 (Del. Ch. Apr. 5, 2006) ("The Delaware Supreme Court has consistently held that directors do not owe fiduciary duties to future stockholders."). Instead, the rights of holders of warrants "are wholly contractual." Aspen Advisors LLC v. United Artists Theatre Co., 861 A.2d 1251, 1263 (Del. 2004). 
from open-ended contracts and residual claimant status, as Easterbrook and Fischel argued. Warrant holders can have both of these attributes, and yet fiduciary duties do not attach to their warrants.

The warrant example demonstrates the flaw in the contractarian argument that voting rights and fiduciary protections follow the residual economic claim. In fact, the nexus of contracts approach to fiduciary duties has the sequence backward. Managers do not owe fiduciary duties to shareholders because shareholders hold the corporation's residual economic interests and it is efficient to unite the two. Managers owe fiduciary duties to shareholders because shareholders have property interests in the residual control of the corporation (through their voting power) and shareholders retain the residual economic interest because it is efficient to unite the two. When a corporation is created, those who contribute assets to it give away their legal rights to the property contributed and retain equitable rights.

This does not at all mean the conventional residual claimant analysis is incorrect, just that it is backward. Property owners choose to retain the right to fiduciary duties because they also choose to retain the economic residual, and it makes sense to keep the two rights together for exactly the reasons the law and economics literature says. But the rights do not come from the economic residual merely because it is generally efficient to unify them. Thus, while the conventional law and economics wisdom is that shareholders are owed fiduciary duties because they hold the residual economic interest and it is efficient to allocate fiduciary rights to the residual holder, the property theory says that, instead, shareholders are owed fiduciary duties because of their proprietary relationship to the corporation. Shareholders choose to retain the residual economic interest because it is efficient to do so.

This way of looking at the corporation and fiduciary duties has several advantages over existing contractarian perspectives. A clear theoretical vulnerability of the contractarian account is that shareholders are not the only residual economic claimants on the corporation. Constituencies other than shareholders stand to benefit or suffer based on the success of 
the corporation, and their interest resembles a residual interest. Moreover, contractarian theory assumes these other constituencies can simply protect their interests through contract, but they face similar challenges to shareholders in protecting their interests through contract, given the impossibility of complete contracts. ${ }^{252}$ Thus, the argument for shareholder primacy which emphasizes the vulnerability of the common stock overlooks the vulnerability of other constituencies. The argument for shareholder primacy based on its residual claim overlooks that there are other residual claimants on the corporation.

The response of contract theorists is that the fact that there are externalities to corporate decisions does not implicate fiduciary duties. Most theorists don't expect boards to take all externalities into account when making decisions ${ }^{253}$ (although there are exceptions ${ }^{254}$ ). For example, good decisions by boards of directors necessarily impose negative externalities on competitors, but those externalities do not trigger the board's fiduciary duties. Thus, the fact that there are externalities does not mean there are multiple holders of residual interests. However, the contractarian argument falls apart here because, as discussed earlier, ${ }^{255}$ there is no "inside" or "outside" the corporation in the contractarian model, and therefore there are no externalities that flow from corporate decision making. All of those who deal with the corporation are contractors, not corporate stakeholders, something the property theory sidesteps. ${ }^{256}$

252 See, e.g., David K. Millon, New Directions in Corporate Law Communitarians, Contractarians, and the Crisis in Corporate Law, 50 WASH. \& LEE L. REV. 1373, 1377-79 (1993) (explaining how this assumption breaks down in light of the fact that other constituencies face challenges in contracting for all contingencies).

253 See, e.g., Elliott J. Weiss, Social Regulation of Business Activity: Reforming the Corporate Governance System to Resolve an Institutional Impasse, 28 UCLA L. REV. 343, 418-19 (1981).

254 See generally Christopher D. Stone, Where the LAW Ends: The SOCIAL CONTROL OF CORPORATE BEHAVIOR (1975).

255 See supra note 31 and accompanying text.

256 This point about externalities is made in different terms by Velasco, supra note 8, at 912-13 (2010). Because Velasco adopts a property view of the corporation, his argument does not founder on this contradiction. 
The idea that fiduciary obligations follow ownership is not free from controversy, even among those who recognize ownership interests in the corporation. Henry Hansmann, for example, clearly associates voting rights with ownership, as discussed earlier. ${ }^{257}$ Under his view, take away the voting right and one takes away ownership. Still, Professor Hansmann argued that the fiduciary obligations to a corporation with all non-voting stock would be to that stock, even though the firm would be a "nonprofit" at that point. 258 The property approach, by directly connecting voting rights to property rights and property rights to fiduciary rights, avoids such unwieldy misalignments of voting rights and fiduciary obligations.

The contractarian perspective gives rise to a profound circularity that further illustrates the defects with a contractual view of common stock. In explaining this circularity it is first necessary to note that the holder of the residual right cannot hold only contract rights in the entity because, by definition, the residual is whatever is left over after the satisfaction of contractual obligations. For this reason, it is incoherent to accord common stockholders specific economic rights in the normal contractual sense. If value is taken away from one party under a normal bilateral contract, it inures to the other party. But if limits were placed on the returns to common shareholders, that value would have nowhere to go because common shareholders are the residual economic claimants. For a similar reason, the notion of taking away (pro rata) contractual rights from common shareholders is incoherent. Suppose a corporation cancels some shares. Unlike the elimination of any other contractual obligation of the corporation, this cancellation does not increase the value of the corporation at all. Relatedly, any special rights the residual claimant would

257 See supra notes 179-183 and accompanying text.

258 See Hansmann, supra note 179 , at 61 . Hansmann analyzed the situation where a widely held public company stripped shareholders of voting rights. In such a case, he argued, "[t]he directors would still be charged, as they are now, with a fiduciary duty to manage the firm on behalf of the shareholders, and that duty would still be supported by the current array of formal and informal sanctions." Id. He argued this was true even though "[t]he result would be a firm that is formally nonprofit," and "[t]he firm's shareholders would be the beneficiaries of the firm, but not its owners." Id. 
negotiate necessarily come at the expense of the residual claimant itself. The residual is the default set of rights in the corporation that remain when contractual obligations are satisfied. Most notably, as the corporation reduces its contractual obligations to act in specific ways, power is returned to the "residual of the residual," which is the voting right of the residual claimant. In other words, the application of an economic theory of the firm to the legal entity of the corporation produces incongruous results.

This circularity plays out in a common issue in private law-the distinction between property rules and liability rules. A key concept of contract in the law and economics movement is the idea of an efficient breach. But what does it mean to have an efficient breach vis-à-vis a residual beneficiary? Any benefit of the breach redounds to the beneficiary. This is, in part, why property rules rather than liability rules apply to the rights of common shareholders in the corporation.

The residual control interest is, in a sense, prior to and more foundational than the residual economic interest-it is the residual of the residual. One can have an organization without a residual economic claimant-many nonprofits are of that nature-but all organizations must have their residual control reside somewhere. In this sense, the residual control right - the voting right-is the irreducible minimum of the organization, and rightfully the locus of ownership.

The analysis above shows how the residual economic claimant analysis, when combined with the nexus of contracts theory, suffers from incoherence. The free-floating theoretical framework of the nexus of contracts simply does not work in its pure form. The conventional rationale of the nexus of contracts school is that fiduciary duties and voting rights follow the residual claimant. But in a pure contractual regime the identity of the residual claimant is affected by the contracts the corporation enters into. Indeed, the residual right that is indispensable is the residual right to full voting powers. This, rather than the economic residual claim on the assets of the corporation, is the relevant form of residuality and the key to understanding the property nature of shares. 


\section{B. How the Theory of the Firm Became a Theory of Corporate Law}

To explain fiduciary duties, the contractarian approach relies on a somewhat reductive argument of contractual incompleteness. If contracts were complete, there would be no need for fiduciary duties because the contract would specify all actions to be taken by managers under all circumstances. ${ }^{259}$ There can be little quarrel with that. But the fact that complete contracts do not imply fiduciary duties does not imply that contractual incompleteness necessarily leads to fiduciary duties. Indeed, as mentioned previously, all contracts are incomplete to some degree. Yet generally, in non-corporate settings incomplete contracts do not lead to judicially imposed fiduciary duties.

Contractarians rely on the concept of the residual economic claimant to distinguish shareholders from other contractual claimants. But this is where the legal argument errs. The theory of the firm is not a theory of the corporation; it was never designed to draw the boundaries around corporate law. ${ }^{260} \mathrm{In}$ stead, it is an economic theory that relies on the residual claimant analysis to explain why parties provide for certain contractual arrangements and not others. By itself, the theory of the firm does not provide content that could inform corporate law.

How did the residual claimant analysis come to dominate analyses in corporate law? The literature took the wrong turn with Eugene Fama's immensely influential article, Agency Problems and the Theory of the Firm. ${ }^{261}$ Fama's objective was to explain how the separation of ownership and control in the large firm can be efficient, even without an "owner" who can discipline management. Along the way, he observed:

259 See Oliver Hart, An Economist's View of Fiduciary Duty, 43 U. ToRONTO L.J. 299, 301 (1993) ("[I]t is only possible to make sense of fiduciary duty in a world where the initial contract is incomplete for some reason.").

260 See Lynn Stout, The Economic Nature of the Corporation, in 2 OxFORD HANDBOOK OF LAW AND ECONOMICS: PRIVATE AND COMMERCIAL LAW 337, 338 (Francesco Parisi ed., 2017).

261 Fama, supra note 40, at 289. 
In this "nexus of contracts" perspective, ownership of the firm is an irrelevant concept. Dispelling the tenacious notion that a firm is owned by its security holders is important because it is a first step toward understanding that control over a firm's decisions is not necessarily the province of security holders. ${ }^{262}$

But Fama's observation actually fits neatly within the property theory of corporate law. What's missing from Fama's stylized large firm by assumption? Voting. Fama's stylized shareholders have no right to exclude. So, ownership is irrelevant, or more accurately, absent, from Fama's firm. But from a legal perspective, even though Fama alternates between using the terms "corporation" and "firm" in his article, Fama's stylized firm is not the same as the corporation.

In any event, the nexus of contracts approach need not be taken literally as excluding all property relationships of the corporation. The nexus of contracts model does not by itself imply that all the firm's relationships are contract rather than property. For example, consider the personal and real property owned by a corporation. This property cannot properly be described as contractual rights of the corporation. ${ }^{263}$ In other words, the corporation's property is "in" the firm, and the firm's rights cannot be characterized as a "contract" right in the legal sense.

The property theory developed in this Article, therefore, is not a "rejection" of the contributions of the nexus of contracts model, even as a way of thinking about the corporation. Like many insights, the contractarian model lends itself to reductivist thinking that collapses all details into a single, simple model. The property theory of corporate law provides an

262 Id. at 290.

263 There are some who have gone that far, arguing that even the corporation doesn't truly own its own assets in a fee simple type way. See Joseph William Singer, The Reliance Interest in Property, 40 STAN. L. REV. 611, 639-41 (1988) (arguing that the separation of ownership and control has eliminated the argument that shareholders own the corporation, and that the notion of the corporation itself as "the owner" of its assets is not a useful way to think about rights in the corporation). In this work, Singer argues for a new property right based in reliance that would give various corporate stakeholders an "ownership" in corporate assets. See id. 
account for the bedrock legal institutions that the contractarian approach cannot adequately explain.

\section{Implications for Theory of the Firm}

The property theory of corporate law is not a theory of the firm, just as the theory of the firm is not a theory of corporate law. But the property theory of corporate law does have implications for the theory of the firm. In particular, the property theory developed in this Article has a strong parallel to the "property rights" literature most prominently associated with Grossman, Hart, and Moore ("GHM"). ${ }^{264}$ The GHM theory of the firm views the residual rights of control, not just the residual economic interest, as a relevant form of ownership in the corporation. GHM conceives of the residual rights of control as "ownership" and views the essential role of ownership as the "ability to exclude others." 265 The influence of GHM on the theory of the firm is enormous; the property rights of GHM are viewed as important as the contract rights that preceded it. 266

The GHM model has strong connections to the property theory of corporate law this Article presents, but addresses a different question. GHM addresses the problem of who should own corporate assets to promote efficient investment in productive activity. The property theory addresses the preliminary question of who does own the assets, a question that is essential to assessing the empirical implications of the theory of the firm. Transaction costs involve transactions, and the default allocation of rights has consequences when there are transaction costs. So, to determine whether transaction costs are significant or not, and what types of costs there are in a given case, we need to know the default allocation of rights. The property theory gives us that default allocation.

264 See Sanford J. Grossman \& Oliver D. Hart, The Costs and Benefits of Ownership: A Theory of Vertical and Lateral Integration, 94 J. PoL. ECON. 691 (1986); Oliver Hart \& John Moore, Property Rights and the Nature of the Firm, 98 J. Pol. Econ. 1119 (1990); Oliver Hart, Firms, Contracts, AND FinANCIAL STRUCTURE (1995).

265 Hart \& Moore, supra note 264, at 1121.

266 See Armour \& Whincop, supra note 225, at 462. 
The property theory also sheds light on the legal functions performed by the corporation as an entity. One is to divide property rights while solving commons and anticommons problems. When ownership of a business is divided, commons problems arise because each owner has an incentive to inefficiently extract benefits from the company. This is why corporate law disables shareholders from directly "using" corporate assets.

At the same time, joint ownership of business assets raises anticommons problems, assuming each shareholder has veto rights. These types of problems explain why limits on the property rights that would otherwise exist are necessary for business organizations. ${ }^{267}$ Property law attempted to solve anticommons problems by allowing shareholders to partition, but this "solution" created yet another anticommons problem: each joint owner could then pull their portion of the assets out of the joint business at any time. Nor can these anticommons problems be solved with contract alone. ${ }^{268}$ Indeed, contract law does not generally deal with commons and anticommons problems because they are irrelevant in the paradigmatic bilateral contracting environment. In contrast, these problems are front and center in corporate law. This is why organizations subject this to a governance mechanism rather than unilateral rights. ${ }^{269}$

The perspective of voting as ownership draws support from an unexpected place-the contractarian perspective of $\mathrm{Al}$ chian and Demsetz. The Alchian-Demsetz paper is often thought of as anti-ownership because it treated shareholders not as "joint owners," but instead as just "investors" alongside bondholders and preferred stockholders. ${ }^{270}$ But actually the rationale of Alchian and Demsetz supports the thesis here that voting rights are ownership rights. They wrote:

If we treat bondholders, preferred and convertible preferred stockholders, and common stockholders and warrant holders as simply different classes of

267 Ricks, supra note 201, at 1342-45.

268 Id. at 1344.

269 Id. at 1345.

270 See Alchian \& Demsetz, supra note 31, at 789 n.14. 
investors-differing not only in their risk averseness but in their beliefs about the probability distribution of the firm's future earnings, why should stockholders be regarded as 'owners' in any sense distinct from the other financial investors? ${ }^{271}$

The cited passage argues that there need not be a unity between the residual economic interest and voting rights, and that non-voting shareholders are "simply investors devoid of ownership connotations." ${ }^{272}$ Thus, even Alchian and Demsetz implicitly regard voting as the touchstone of ownership, even though, as they point out, there need not be unity between the economic and control residuals.

In addition to these theoretical mismatches, the nexus of contracts approach has struggled to explain important features of corporate law and struggled to inform how cases should be decided. Melvin Eisenberg pointed out nearly two decades ago that the nexus of contracts theory couldn't literally mean that the firm is just a collection of contracts in legal terms, writing:

The conception neither can nor does mean what it literally says. In ordinary language, the term contract means an agreement. In law, the term means a legally enforceable promise. Pretty clearly, however, the nexus-of-contracts conception does not mean either that the corporation is a nexus of agreements or that it is a nexus of legally enforceable promises. ${ }^{273}$

Eisenberg suggests that instead "the corporation is a nexus of reciprocal arrangements." ${ }^{274} \mathrm{He}$ notes that the term "contracts" originated because economists coined it, and to economists "contracts" simply meant "markets" rather than the Coasean notion of non-market fiat or authority. ${ }^{275}$ As one example of the muddied boundaries between contract and property law, Fama makes it clear that he isn't distinguishing between contract and property in a legal sense, noting that

$271 I d$.

272 Id.

273 Eisenberg, supra note 1, at 822 (emphasis in original).

274 Id.

275 Id. at $822-23$. 
"because of [the nexus of contracts theory's] emphasis on the importance of rights in the organization established by contracts, this literature is characterized under the rubric "property rights." 276 Here, Fama equates contract rights with property rights, showing that a hard distinction was not intended to delineate between the concepts.

There are ways of thinking about the nexus of contracts theory that are not inconsistent with the property theory developed in this Article. One version of the nexus of contracts theory simply seeks to explain the dominant enabling function of corporate law, as contrasted against its limited mandatory features. This "facilitative" or "private law" view of corporations is often contrasted with a public perspective that emphasizes mandatory rules, regulation, and governmental intervention. ${ }^{277}$ It may be better to think of the contractarian school as merely placing corporate law within the private law tradition as opposed to the public law tradition. ${ }^{278}$

Another way of looking at this Article's connection to the contractarian approach is by finding that the nexus of contracts approach applies a Coasean argument to suppliers of capital. Instead of asking why inputs to production are manufactured within a firm instead of across markets, one could ask why capital is supplied by bringing suppliers of capital into the firm (shareholders) instead of solely borrowing in the capital markets. Presumably there are high transaction costs associated with writing contracts with residual holders, so instead the bargaining process is suppressed by bringing some suppliers of capital "inside" as shareholders. This, however, is actually supportive of the idea that there is a non-contractual relationship between shareholders and the corporation.

The problem is not exactly one with the theory of the firm as applied to corporate law. Although the economic theory of the firm eventually "moved on" to the GHM model, the theory of corporate law is still largely contractarian. ${ }^{279}$ In a sense, the

276 Fama, supra note 40, at 289.

277 See, e.g., Marc T. Moore, Corporate Governance in the Shadow of THE STATE 1-6 (2013).

278 See GREENFIELD, supra note 72, 29-33.

279 Armour \& Whincop, supra note 225, at 462. 
role of this Article and the new property perspective on corporate law is to take the first steps down the road toward integrating the insights of the GHM model into the theory of corporate law.

\section{THE IMPLICATIONS FOR CORPORATE LAW}

The nexus of contracts model does not actually solve many problems in corporate law. Indeed, those in the debate often struggle to identify specific reasons why it matters. ${ }^{280}$ There are several reasons for this. First, as mentioned above, the nexus of contracts theory does not have many implications; it is largely an imprimatur on the status quo. ${ }^{281}$ Second, without a boundary line between property and contract, the contractarian model does not do much work in identifying how or why corporate law differs from ordinary contract law. ${ }^{282}$ Third, in many defenses of shareholder ownership of the corporation, the most significant justification offered is that of "shareholder primacy." 283 Critics counter that ownership is not a serious explanation for the concept of shareholder primacy. ${ }^{284}$

Moreover, the nexus of contracts approach does the most work in academic analyses precisely where its rationale is weakest-in accounting for the fiduciary duties of the various contractual claimants on the corporation. It does much of its work here because most of the other contractual claims on the corporation (those of employees, creditors, etc.) are governed by other branches of specialized contract law. The argument that contractual incompleteness is the foundation for fiduciary duties is weak because, as noted above, contractual

280 For example, Eisenberg's article objecting to the nexus of contracts comparison cites "what is at stake" as the ideas of "getting things right" and "clear thinking." See Eisenberg, supra note 1, at 836.

281 See supra notes 1-17 and accompanying text.

282 See supra notes 46-65 and accompanying text.

283 See Velasco, supra note 8, at 939-40 (arguing that the fact of shareholder ownership matters because property provides a stronger foundation for shareholder rights than contract, and implies shareholder primacy and director accountability to shareholders).

284 See GREENFIELD, supra note 72, at 47 ("No prominent contemporary corporate law scholar uses property rights as the primary rationale for shareholder dominance."). 
incompleteness does not give rise to fiduciary duties in other contexts. ${ }^{285}$

The introduction of the property theory allows us to classify the various claims on the corporation and discuss the meaningful implications for corporate law moving forward. This property conception explains a lot of legal patterns we observe and clarifies otherwise puzzling legal rules. Most of the answers provided by the property theory revolve around the thorny problems created by the slipperiness of the residual claimant justification. Some preliminary implications are sketched out in this Part.

\section{A. Contractual Rights in the Charter}

The Delaware courts routinely characterize corporate charters and bylaws as "contracts" between the corporation and its shareholders ${ }^{286}$ or just among the shareholders themselves. ${ }^{287}$ The contractual nature of the charter and bylaws appears most frequently in interpretive contexts, in which Delaware courts apply principles of contract interpretation to these documents. ${ }^{288}$ Because the charter and bylaws are the

285 See supra notes 118-21 and accompanying text.

286 See, e.g., Boilermakers Local 154 Ret. Fund v. Chevron Corp., 73 A.3d 934, 955 (Del. Ch. 2013) ("In an unbroken line of decisions dating back several generations, our Supreme Court has made clear that the bylaws constitute a binding part of the contract between a Delaware corporation and its stockholders.").

287 See, e.g., Centaur Partners, IV v. Nat'l Intergroup, Inc., 582 A.2d 923, 928 (Del. 1990) ("Corporate charters and by-laws are contracts among the shareholders of a corporation and the general rules of contract interpretation are held to apply."). Although older cases can be found with this contractarian perspective on the charter, most famously Trs. of Dartmouth Coll. v. Woodward, 17 U.S. (4 Wheat.) 518 (1819), the contractarian perspective has increased in intensity in the last few decades. This perspective reached a high-water mark recently where the Delaware Supreme Court validated a unilateral bylaw amendment by the board based on the contractual nature of the bylaws. In ATP Tour, Inc. v. Deutscher Tennis Bund, the court reasoned that because "corporate bylaws are "contracts among a corporation's shareholders," a fee shifting provision could be adopted by the board. See 91 A.3d 554, 558 (Del. 2014) (quoting Airgas, Inc. v. Air Prods. \& Chems., Inc., 8 A.3d 1182, 1188 (Del. 2010)).

288 See ATP Tour, Inc., 91 A.3d at 558. 
place where the rights of stockholders qua stockholders are set forth, on the surface this might suggest that holders of stock retain only contractual claims.

The often overlooked fact, however, is that the important rights of the common stock are not typically expressed in the corporate charter. The rights of common stock are generally standard, off-the-rack terms provided by law in the relevant corporate code. ${ }^{289}$ These rights include the scope of fiduciary duties and voting rights, both of which emerge from corporate statutes and the corresponding case law, not from the terms of the charter. ${ }^{290}$ This is demonstrated by the fact that virtually all of the cases interpreting charters as contracts relate to preferred stock provisions, which are special rights different from residual rights under corporate law. ${ }^{291}$ Special rights expressed in the charter are not the residual rights of common stock that constitute ownership interests.

The Delaware courts' nonstandard approach as to when provisions are contractual and when they are fiduciary forces courts into contortions to explicate how contractarian doctrine explains basic principles of corporate law. For example, in the recent case of Sciabacucchi v. Salzberg, the Chancery Court explained:

The certificate of incorporation differs from an ordinary contract, in which private parties execute a private agreement in their personal capacities to allocate their rights and obligations. When accepted by the Delaware Secretary of State, the filing of a certificate of incorporation effectuates the sovereign act of creating a "body corporate"-a legally separate entity. . . . When doing so, Delaware deploys the corporate law to

289 See EASTERBROOK \& FiSCHEL, supra note 2, at 34 (describing corporate law as a "set of terms available off-the-rack," including voting rights and fiduciary obligations).

290 See id.

291 See, e.g., Boilermakers Local 154 Ret. Fund v. Chevron Corp., 73 A.3d 934, 955 (Del. Ch. 2013). 
determine the parameters of the property rights that the state has chosen to create. ${ }^{292}$

In this excerpt, the court begins with a contractarian approach and eventually relents by invoking the concept of "property rights" in the certificate of incorporation. The case was eventually reversed by the Delaware Supreme Court, which opted for a "continuum" approach to what is "internal" and "external," rather than a binary one. ${ }^{293}$ It would be easier to just ignore the contractual gymnastics and start with the property conception of corporate law, which readily lends itself to the "continuum" approach.

Nexus of contract theorists have struggled to explain why substantially all companies accept the "off-the-rack" default terms of corporate law. If corporate law is truly contractual, why are there generally no negotiated terms? As Michael Klausner points out, "there actually is no significant diversity in corporate contracts - that is, in either charter terms or in the corporate law rules that firms adopt via their incorporation choices. The diversity that exists is not contractual. And the contracts that exist are not diverse." ${ }^{294}$ That is, corporate "contracts" (charters) tend to contain few provisions and rely mostly on state law. ${ }^{295}$ In other words, with few exceptions, "default rules are uniformly adopted." 296 Still, even if uniformity is efficient, commercial actors could easily create standard forms themselves, so why rely on a state government with no obvious comparative advantage in the supplying of terms to perform the task? ${ }^{297}$ This reliance on the default rules of corporate law is a puzzle for the contractarian theory. ${ }^{298}$

292 Sciabacucchi v. Salzberg, C.A. No. 2017-0931-JTL, 2018 WL 6719718, at *2 (Del. Ch. Dec. 19, 2018), rev’d, C.A. No. 2017-0931, 2020 WL 1280785 (Del. Mar. 18, 2020).

293 Salzberg v. Sciabacucchi, C.A. No. 2017-0931, 2020 WL 1280785, at *18 (Del. Mar. 18, 2020).

294 Michael Klausner, The Contractarian Theory of Corporate Law: A Generation Later, 31 J. CORP. L. 779, 784 (2006).

295 Id. at 786.

296 Id. at 790.

297 See Armour \& Whincop, supra note 225, at 430-31.

298 Klausner argues that network effects might be one reason why. See Michael Klausner, Fact and Fiction in Corporate Law and Governance, 65 
The property theory of corporate law offers one account for this reliance that goes beyond the traditional explanations of prohibitively high transaction costs and (more recently) challenging network effects. ${ }^{299}$ As explained above, the default rules of corporate law provide the boundaries of the property rights of shareholders in the corporation. By deviating from those default terms and creating rights different from those provided by corporate law, practitioners may sense there is a risk that rights previously conceived of as property rights will cross over into being considered contract rights. Those rights could then lose their fiduciary protection. Corporate shares are (or are perceived to be) more valuable with those protections than without, and thus the default property rights corporate law provides are generally retained. Moreover, in a sense these default rules are not an "off the rack" standard form contract because they change over time as corporate law evolves. That feature, too, is more one of property than of contract. The fact that shareholders have no explicit terms leads more plausibly to the conclusion that they have full property rights with standard contract law limitations provided by the state.

\section{B. Fiduciary Duties to Holders of Preferred Stock, Warrants, and Convertible Securities}

The contractarian rationale for fiduciary duties provides an unsatisfactory account of current fiduciary law as it relates to preferred stock, warrants, and convertible securities. As Part IV explained, the economic residual claimant argument is both over- and under-inclusive. These problems are particularly acute in the case of complex capital structures. As

STAN. L. REV. 1325, 1329-30 (2013). The more parties adopt a term the greater value it has. However, this fails to account for the fact that parties rely on defaults much more in corporate law than in any other area of contracting. There is something unique about corporate law that makes sophisticated parties unlikely to deviate from defaults. Another argument from Henry Hansmann is that reliance on the default makes the contract flexible and delegates to the state the responsibility of periodically revising the corporate "deal" in light of changing circumstances. See Henry Hansmann, Corporation and Contract, 8 AM. L. \& ECON. REV. 1, 2 (2006).

299 See Klausner, supra note 294, at 1329-30. 
discussed above, various types of claims on the corporation have residual aspects from an economic perspective, especially warrants and convertible securities (whether the securities are debt or preferred stock). ${ }^{300}$ This makes the application of the nexus of contracts theory particularly challenging in the context of complex capital structures.

The legal rules in this area are far simpler than the residual claimant analysis would suggest. Boards owe fiduciary duties to common stockholders and, to a more limited extent, preferred stockholders. ${ }^{301}$ They do not, however, owe fiduciary duties to holders of warrants or convertible securities. ${ }^{302}$ The holders of such securities must protect their interests through contract, which they universally do. ${ }^{303}$ This is in spite of the fact that such securities clearly have residual interests in the corporation, and may indeed have a substantially identical residual economic interest to that of the common stockholders, depending on their terms. Thus, here the existing legal rule conflicts with the murky economic residual analysis.

The failure to apply the property theory approach has caused a legal mess in the preferred stock context, where a pure contractarian perspective makes sorting out conflicting loyalty problems especially tricky. Preferred stock is not any single "thing." Its attributes can vary widely from instrument to instrument, depending on what the investor negotiates with the company. As a result, the legal attributes of preferred stock draw from both contract law and corporate law, with a somewhat ad hoc allocation from one category or the other. ${ }^{304}$

300 See supra Section IV.A.

301 See, e.g., In re Trados Inc. S'holder Litig., 73 A.3d 17, 39-40 (Del. Ch. 2013) ("Preferred stockholders are owed fiduciary duties only when they do not invoke their special contractual rights and rely on a right shared equally with the common stock.").

302 See Aspen Advisors LLC v. United Artists Theatre Co., 861 A.2d 1251, 1263 (Del. 2004) (finding that the "convertibility feature of warrants" and convertible stock does not "impart stockholder status").

303 See Alexander J. Triantis \& George G. Triantis, Conversion Rights and the Design of Financial Contracts, 72 WASH. U. L.Q. 1231, 1252-53 (1994).

304 William W. Bratton \& Michael L. Wachter, A Theory of Preferred Stock, 161 U. PA. L. REV. 1815, 1820 (2013) ("Preferred stock sits on a fault 
Approaches to preferred stock vary widely in terms of the fiduciary protection such stock receives. ${ }^{305}$

In the preferred stock context the applicable legal rules are somewhat clear on their facts but murky in their application when viewed through the contractarian paradigm. As "stock," preferred stock is owed fiduciary duties. However, the Delaware courts have indicated that the fiduciary obligations of boards of directors to preferred stockholders go only as far as the interests of the preferred stock coincide with those of the common stock. ${ }^{306}$ Beyond that, in the realm of the "special rights" of the preferred, boards' obligations are generally to favor the interests of the common stock. ${ }^{307}$ This description raises the questions of whether a board could ever have a fiduciary duty to the preferred over the common, and whether the two classes could even be placed on an equal fiduciary footing where their interests differ.

In contrast to the contractarian view, the property approach provides a framework for analyzing the potentially conflicting loyalty obligations that arise in the context of preferred stock, convertible securities, warrants, and the like. One source of confusion in the contractarian approach is the tension between the idea that fiduciary duties attach to residual economic rights and the black letter legal principle that fiduciary duties do not attach to warrants or conversion privileges. The property theory resolves this tension by showing that fiduciary duties do not necessarily follow the residual

line between two great private law paradigms, corporate law and contract law.”).

305 Others take the position that fiduciary protections should not apply to sophisticated preferred stockholders such as venture capitalists. See, e.g., Charles R. Korsmo, Venture Capital and Preferred Stock, 78 BRoOK. L. REV. 1163, 1166-67 (2013) (arguing that "VC holders of preferred stock should never be afforded fiduciary protections, and they should always be required to rely on the protections of their contract").

306 See, e.g., In re Trados Inc., 73 A.3d at 39-40.

307 See Equity-Linked Inv'rs, L.P. v. Adams, 705 A.2d 1040, 1042 (Del. Ch. 1997) ("[G]enerally it will be the duty of the board, where discretionary judgment is to be exercised, to prefer the interests of common stock-as the good faith judgment of the board sees them to be-to the interests created by the special rights, preferences, etc., of preferred stock, where there is a conflict."). 
economic interest. The primary obligation of directors is to the stockholding residual voting interests (always at least one class of common stock, but may also include classes of preferred stock). The fiduciary rights of preferred stockholders confer standing to sue for injuries to common stockholders. But as contract rights, the special features of preferred stock are not protected by fiduciary obligations.

This analysis also makes it clear that the relevant distinction is not between boards' duties to common stockholders and preferred stockholders, but between boards' duties to property interests versus contract interests. Although common stock's default rights are property interests, common stockholders may also have contract rights; and although preferred stock's special rights are contractual, the preferred may also have property rights. Thus, boards' fiduciary duties do not attach to the holders of one stock or the other by virtue of a label or a residual economic interest, but to property interests in the corporation.

The property theory helps to explain the otherwise challenging tension between some recent high-profile Delaware cases on preferred stock. The first relevant case to this tension is Orban v. Field, where the Chancery Court was tasked with sorting out the contractual from the "fiduciary" rights of preferred stockholders. ${ }^{308}$ Orban gave rise to an apparent "control-contingent approach" where fiduciary duties to various classes vary depending on which class controls the board. 309 This approach would suggest that when common stockholders are in control of the board, directors can favor common stockholders over preferred stockholders. ${ }^{310}$ But, under this approach, preferred-dominated boards can favor the preferred over the common, at least when doing so favors the overall best interests of the corporation. ${ }^{311}$ The Delaware Chancery

308 Orban v. Field, C.A. No. 12820, 1997 WL 153831, at*8 (Del. Ch. Apr. 1, 1997).

309 See In re Trados Inc., 73 A.3d at 42 n.16 (citing Jesse M. Fried \& Mira Ganor, Agency Costs of Venture Capitalist Control in Startups, 81 N.Y.U. L. REV. 967, 1021 (2006)).

310 Fried \& Ganor, supra note 197, at 1021.

311 See id. at 999-1000. 
Court distanced itself from the control-contingent approach in Trados. ${ }^{312}$

The control contingent approach often reaches correct results, but for the wrong reasons, and property theory shows why. When preferred stockholders are in control of the corporation's voting interests, especially when they are in control of the vast majority of the corporation's voting interests, directors favoring the voting interest usually has the effect of favoring the preferred over the common. When the preferred is in the minority, directors favoring the voting interest usually has the effect of favoring common stockholders over preferred stockholders. Thus, the property approach resolves these otherwise bewildering twists and turns without the need to rely on additional sub-rules, as the control-contingent approach does.

The property theory also explains why the liquidation preference of preferred stock should not receive special fiduciary protection. As to the liquidation preference, the situation of preferred stockholders in many of these circumstances is similar to that of debt holders in insolvency, as discussed below. ${ }^{313}$ When the value of a company is less than the liquidation preference of its preferred shares, the preferred shares become the de facto residual claimant of the firm. Yet Delaware courts do not analyze the fiduciary duties owed to preferred stockholders in this way. Instead, they rely on the contractual/non-contractual dichotomy. ${ }^{314}$ This approach of the Delaware courts is further evidence that the de facto residual claimant approach is not the right one from a legal perspective.

\section{Dual-Class Stock and Other Non-Standard Capital Structures}

The previous Section leads naturally into a discussion of the treatment of dual-class stock. The question of dual-class stock with differential voting rights has posed a problem in

312 In re Trados Inc., 73 A.3d at 42 n.16. There, speaking for the court, Vice Chancellor Laster stated that "[t]he control-contingent interpretation does not comport with how I understand the role of fiduciary duties." Id.

313 See infra Section V.B.

314 See, e.g., In re Trados Inc., 73 A.3d at 39-40. 
corporate law for decades. The debate has become more salient recently with some of the largest technology companies in the world adopting these structures, which effectively make control uncontestable, ${ }^{315}$ and in some cases limit public sales to only non-voting stock. ${ }^{316}$

There is a debate over the desirability of such structures. Some scholars have recently argued dual-class structures or even non-voting shares may promote efficiency. ${ }^{317}$ In many cases, the motivation ascribed to the controller relates to the private benefits of control, in which the controller seeks to take a disproportionate share of the value of the company. ${ }^{318}$ But such a motivation held by the controller of the corporation exposes public shareholders to the risk of increased agency costs. ${ }^{319}$

The property theory resolves potential tensions associated with fiduciary duties readily, to the extent there are conflicts (which in most cases there are not). First, the property interest in the corporation attaches to a corporation's voting shares. The analysis in this Article implies that voting interests are therefore the primary beneficiaries of fiduciary duties, to the extent that there is a conflict with non-voting

315 Goshen \& Hamdani, supra note 174, at 590 (noting that Facebook, Google, and many others have created dual-class structures that effectively deprive public investors of meaningful control).

316 See Dorothy S. Lund, Nonvoting Shares and Efficient Corporate Governance, 71 STAN. L. REV. 687, 690 (2019) (noting that Snap, Inc. was the first company to conduct an IPO selling only non-voting stock to the public).

317 See, e.g., Goshen \& Hamdani, supra note 174, at 576-93 (arguing that dual-class stock may help to preserve an entrepreneur's "idiosyncratic vision" to achieve above-market returns); Lund, supra note 316, at 693 n.26 (arguing that non-voting shares can make corporate governance more efficient by allocating votes to those who value them the most).

318 See Goshen \& Hamdani, supra note 174, at 565. A more ambivalent version of the private benefits of control theory is that the private benefits are a form of compensation for the monitoring function performed by the controlling shareholder, and therefore are not unambiguously bad. See id. Goshen and Hamdani hypothesize an alternative reason for corporate control that does not rely on private benefits-that corporate control allows the entrepreneur to pursue his or her "idiosyncratic vision" aimed at producing above-market returns. See id. at 577-78.

319 See id. at 590-91. 
interests. When a class of non-voting stock is created with economic rights identical to those of common stock, Delaware courts have held that, as a general matter, the non-voting class is entitled to fiduciary duties. ${ }^{320}$ Rather than viewing these rights as primary fiduciary rights, however, Delaware courts conceive of them more in the nature of standing rights to sue derivatively for harms to the corporation as a whole, just as in the case of preferred stock.

This stock versus non-stock distinction (granting standing to sue) is what makes preferred stock and non-voting stock different from mere contracts, such as warrants. But for the reasons discussed in this Article, the duty of loyalty attaches to voting shares specifically, to the extent that the rights of the voting shares conflict with the special rights of the nonvoting shares. Special contractual rights will not, in and of themselves, receive the benefit of fiduciary duties.

One of the central points of this Article is that ownership interests are not necessarily unique to a single class of stock, nor are they the proper way to characterize all claims on the corporation. Common stockholders, preferred stockholders and holders of non-voting stock will all hold some contractual claims and some proprietary claims. The proprietary claims are those entitled to the protection of fiduciary duties. Nonvoting stock is essentially a contract right coupled with the standing to sue for fiduciary violations, provided by its status as stock.

This conclusion is initially jarring, but actually fits neatly into the structure of existing corporate law. First, non-voting stock is economically equivalent to a warrant, which also lacks voting rights and fiduciary protections. Second, protecting the voting stock that retain identical economic rights to the nonvoting class will in turn protect the non-voting stock. Third, in cases where there are multiple classes with different voting rights, the non-voting (or lesser voting) common stock generally receives explicit contractual protections that are not provided to other common stockholders. Indeed, these non-voting classes of stock resemble a class of preferred that is designed

320 See In re FLS Holdings, Inc. S’holders Litig., C.A. No. 12623, 1993 WL 104562, at *4 (Del. Ch. Apr. 2, 1993). 
to mirror the economic arrangement of common stock. That suggests that the rights of the non-voting shares are contractual, much like that of "phantom stock," which is designed to mirror the terms of common stock. ${ }^{321}$ Finally, the fact that non-voting stock may not have fiduciary protections identical to that of voting common stock does not leave it without any protection against directors' discretion, even for its special rights. Holders of those contractual rights would be protected by the implied covenant of good faith and fair dealing, even if not fiduciary protections vis-à-vis the common voting stock. ${ }^{322}$

Applying fiduciary protections primarily to voting stock also fits within existing corporate law. Self-dealing transactions are normally subject to entire fairness scrutiny. ${ }^{323}$ However, voting shareholders can ratify or "cleanse" such transactions by a majority vote. Whether under Delaware's Section $144^{324}$ or the Model Business Corporation Act's Subchapter $\mathrm{F},{ }^{325}$ conflict of interest transactions can be cleansed by a majority vote of disinterested shareholders. It is the shareholders entitled to vote who have the ability to sanitize fiduciary

321 See generally D. Kyle Sampson, Comment, The Fiduciary Duties of Corporate Directors to "Phantom" Stockholders, 62 U. CHI. L. REV. 1275 (1995).

322 This situation is not unusual, resembling closely the position of passive investors in Delaware LLCs in which all fiduciary duties have been eliminated in the operating agreement, as permitted by Delaware law. See 6 Del. Code Ann. § 18-1101(b) (2019); R \& R Capital, LLC v. Buck \& Doe Run Valley Farms, LLC, C.A. No. 3803-CC, 2008 WL 3846318, at *4 (Del. Ch. Aug. 19, 2008); Myron T. Steele, Judicial Scrutiny of Fiduciary Duties in Delaware Limited Partnerships and Limited Liability Companies, 32 DEL. J. CORP. L. 1, 9 (2007) ("Absent evidence to the contrary, it must be assumed that passive investors who authorize, in the unincorporated business entities' enabling documents, the elimination or restriction of one or more fiduciary duties are fully informed of the risks and benefits.").

323 See, e.g., In re Trados Inc. S'holder Litig., 73 A.3d 17, 56 (Del. Ch. 2013) ("A reviewing court deploys the entire fairness test to determine whether the members of a conflicted board of directors complied with their fiduciary duties.").

324 See Del. Code ANN. tit. 8, § 144 (2019).

325 See Model Bus. Corp. Act $\S 8.62$ (Am. Bar Ass'N 2016). 
violations, and no other shareholders. ${ }^{326}$ This makes sense under the property theory, where such fiduciary violations are violations only as to the voting stock, and therefore only the voting stock is able to cleanse them.

\section{Fiduciary Duties in the Zone of Insolvency}

One of the most fraught areas of corporate law is the question of whether and when duties shift away from shareholders as corporations approach insolvency. ${ }^{327}$ As the net worth of a corporation declines and the prospect of recovery for shareholders grows more and more remote, should the fiduciary duties owed to shareholders shift to the debt holders? Corporate law practitioners have long wondered whether directors of companies in the zone of insolvency owed their fiduciary duties to the company's creditors, which influential Delaware opinions seemed to suggest. ${ }^{328}$ The issue was resolved (for now) against the concept of shifting duties in the zone of insolvency. ${ }^{329}$ But what about corporations that are actually insolvent?

326 Both the DGCL and the MBCA refer specifically to the shareholders "entitled to vote" as those relevant for the purpose of cleansing conflict of interest transactions. See supra note 195 and accompanying text.

327 See N. Am. Catholic Educ. Programming Found., Inc. v. Gheewalla, 930 A.2d 92, 99-101 (Del. 2007) (explaining that many judicial opinions and scholarly articles had addressed this issue, and acknowledging that "the need for providing directors with definitive guidance compels [the court] to hold that no direct claim for breach of fiduciary duties may be asserted by the creditors of a solvent corporation that is operating in the zone of insolvency").

328 Credit Lyonnais Bank Nederland, N.V. v. Pathe Commc'ns Corp., C.A. No. 12150, 1991 WL 277613, at *34 (Del. Ch. Dec. 30, 1991) ("[W]here a corporation is operating in the vicinity of insolvency, a board of directors is not merely the agent of the residual risk bearers, but owes its duty to the corporate enterprise.").

329 Gheewalla, 930 A.2d at 101 ("When a solvent corporation is navigating in the zone of insolvency, the focus for Delaware directors does not change: directors must continue to discharge their fiduciary duties to the corporation and its shareholders by exercising their business judgment in the best interests of the corporation for the benefit of its shareholder owners."). Further, the mention of "owners," although imprecise, highlights the connection between property and fiduciary duties in this context. 
The problem is difficult because there is nothing qualitatively different about a corporation in the zone of insolvency or even in insolvency from a thriving corporation. The distinction is one of degree. In a healthy corporation common stockholders hold the equivalent of an option, and the same is true in an unhealthy company. In both companies the option is merely "in the money" in the first case and "out of the money" in the other.

The perceived problems with the "insolvency" or "zone of insolvency" issues are really no different from the issues faced in the case where negative externalities are inflicted on other stakeholders of the corporation. In a solvent corporation, a board does not violate its fiduciary duties by failing to consider the interests of constituencies other than shareholders in making decisions. For this reason, a board can close a factory, even if the economic harm of closing the factory outweighs the benefit to the corporation (or its shareholders). ${ }^{330}$ In other words, boards are not required to internalize all costs associated with their decisions to make the most efficient decision from a societal perspective. This is as true when the claimant is a financial one, such as a creditor, as it is when the claimant has other interests, such as those of an employee.

The economic intuition behind the shifting duties in the insolvency context is cogent. There is a worry that allegiance to shareholders (who, in the insolvency case, hold out of the money options) will encourage negative expected value gambles, because the shareholders do not internalize the risk to the debt holders. ${ }^{331}$ But this problem has nothing to do with corporate entities specifically; this is a feature of all debt, even

330 The law has long been reasonably settled that directors are not required to trade off the interests of other constituencies against those of the shareholders. Indeed, there is a debate as to whether the directors even may trade off those interests, a concern that led to the enactment of so-called "constituency" statutes in various states. See Comm. on Corp. Laws, Other Constituencies Statutes: Potential for Confusion, 45 Bus. LAW. 2253, 225461 (1990).

331 See, e.g., Frederick Tung, The New Death of Contract: Creeping Corporate Fiduciary Duties for Creditors, 57 EMORY L.J. 809, 821 (2008) (explaining how shareholders may even prefer negative expected value gambles because of their limited liability). 
that owed by individuals. This is one important reason why bankruptcy law and fraudulent transfer law exist. Corporate law could not protect creditors where an individual was insolvent, and it does not provide the primary protection for creditors when a corporation is insolvent.

The reason why the insolvency discussion appears to cause problems is because of the residual claimant analysis, which the property theory sidelines. If shareholders are owed fiduciary duties because they are residual claimants, then those fiduciary duties should shift when they are no longer residual claimants. When a firm is "underwater," the voting rights in the firm should follow the residual rights and shift from shareholders to creditors. ${ }^{332}$ One could distinguish shareholders because shareholders are entitled to whatever is left in the corporation after fixed claims are paid. ${ }^{333}$ In this sense, shareholders' residual claims are qualitatively different than those of other residual claimants. The same is true for debt claims when a corporation is insolvent. This is one potential justification for treating externalities of the debt differently from externalities generally - the debt holders may become "residual" in the sense of being entitled to a payout of whatever is left.

But if instead fiduciary duties are based on ownership as determined by voting power, things become much simpler. In that case, boards should remain loyal to their shareholders' interests until the filing of a bankruptcy petition. Why? Because other law protects creditors, but no other law protects shareholders.

This rule resonates well with recent Delaware decisions rejecting the shift of fiduciary duties to debt holders in the "zone of insolvency." 334 However, it also helps to explain otherwise problematic decisions relevant to corporations in insolvency. Consider the Delaware Chancery Court's recent analysis in the insolvency context:

When directors of an insolvent corporation make decisions that increase or decrease the value of the firm as

332 Easterbrook \& Fischel, supra note 48, at 404.

333 See Velasco, supra note 8, at 912-13.

334 See Gheewalla, 930 A.2d. at 103. 
a whole and affect providers of capital differently only due to their relative priority in the capital stack, directors do not face a conflict of interest simply because they own common stock or owe duties to large common stockholders. Just as in a solvent corporation, common stock ownership standing alone does not give rise to a conflict of interest. The business judgment rule protects decisions that affect participants in the capital structure in accordance with the priority of their claims. ${ }^{335}$

If corporate law requires fidelity to voting interests even in the periphery of insolvency, how is it that those duties are transferred in bankruptcy? Federal bankruptcy law takes over and supersedes corporate law voting rules in providing voting rights to creditors. ${ }^{336}$ Specifically, "[a]fter a chapter 11 petition has been filed, corporate voting is governed by a federally imposed bankruptcy system," in which "every holder of a claim or interest" is entitled to vote on the reorganization plan, with certain exceptions. ${ }^{337}$ What federal bankruptcy law is doing here is enlarging creditors' ownership interests in the corporation.

The insolvency analysis illustrates the inadequacy of the economic residual claimant analysis in the case of fiduciary duties. It is unworkable to require constant evaluation of who the residual claimant is based on the fluctuating financial prospects of the corporation. Such a standard would involve fiduciary duties changing day to day. The property theory provides a much more secure guide: fiduciary duties remain focused on the voting interests of the corporation until the identity of the voters changes.

Indeed, even strong proponents of shareholder ownership argue that owing fiduciary duties to creditors of insolvent corporations is consistent with the theory of shareholder

335 Quadrant Structured Prods. Co. v. Vertin, 115 A.3d 535, 547-48 (Del. Ch. 2015).

336 See David Arthur Skeel, Jr., The Nature and Effect of Corporate Voting in Chapter 11 Reorganization Cases, 78 VA. L. REV. 461, 462-63 (1992).

337 Id. 
ownership. ${ }^{338}$ But such a claim is necessarily based on the "residual claimant" analysis, which becomes complicated in the case of insolvency. The property theory developed here-in which voting rather than economic rights drive the analysisbetter accounts for the current state of the case law.

\section{E. Social Purposes of the Corporation}

This Article's sketch of a property theory of corporate law would not be complete without briefly considering the shareholder-stakeholder debate and the question of the social purpose of the corporation. The debate over which constituencies directors should consider in making decisions and what directors should maximize is a generations-old conversation that remains vibrant today. ${ }^{339}$

The debate over the proper objective function of the corporation intersects with the debate over the contractarian perspective on the corporation in complex and subtle ways. The contractarian debate is often complicated with issues of shareholder primacy because many theorists (often implicitly) link the recognition of property interests in the corporation to a single-minded shareholder wealth maximization directive. ${ }^{340}$ Indeed, the idea that a property approach implies a purely shareholder-based model is one of the few things that many commentators on both sides of the stakeholder debate agree on. ${ }^{341}$ Yet that view is overly simplistic, not to mention the fact that the contractarian perspective has also traditionally been used to justify the shareholder primacy model. ${ }^{342}$

338 See, e.g., Velasco, supra note 8, at 932-33.

339 The classic dialogue on this issue was the famous Berle-Dodd debate. See A. A. Berle, Jr., Corporate Powers as Powers in Trust, 44 HarV. L. REV. 1049, 1049 (1931) (arguing that the corporate powers are "at all times exercisable only for the ratable benefit of all the shareholders as their interest appears"); E. Merrick Dodd, Jr., For Whom Are Corporate Managers Trustees?, 45 HARV. L. REV. 1145, 1148 (1932) (arguing that the corporation should be operated for the benefit of multiple constituencies as it "has a social service as well as a profit-making function").

340 See supra notes 57-65 and accompanying text.

341 See Velasco, supra note 8, at 940-52.

342 See, e.g., Millon, supra note 252, at 1377-78 (explaining that the contractarian approach argues that state law supplies the terms of the 
The argument that shareholder ownership implies the necessity of shareholder primacy is grounded in traditional thinking about the ownership of the corporation. The shareholder ownership model is generally thought of as the traditional approach, however stakeholder theorists often argue that the traditional ownership model is incorrect in that shareholders do not "own" the corporation. ${ }^{343}$ Therefore, stakeholder theorists maintain that the implications that flow from the traditional model (such as the necessity of shareholder primacy) lack a justification. ${ }^{344}$

In reality, the contractarian approach can be turned toward a stakeholder or communitarian perspective. ${ }^{345}$ This has led some stakeholder theorists to a lukewarm embrace of the nexus of contracts approach, where the possibility exists for treating all contractual claimants evenhandedly. ${ }^{346}$ The progressive/communitarian perspective often embraces the notion of the firm as a "nexus" or "web" of contracts. ${ }^{347}$ Proponents then turn on the theory for its implications that the governance of the corporation is of "private," not "public" concern. ${ }^{348}$

However, in many respects this line of reasoning about property and contract as they relate to the social purposes of the corporation conflates two separate crosscutting issues that confuse the debate. One is the allegiances owed by fiduciaries of the corporation. The communitarian approach often advances a "multifiduciary model" in which directors would

"contract" that mandates directors' loyalty to shareholders' interest in wealth maximization).

343 Stout, supra note 89, at 1190-92.

344 See, e.g., James E. Post et AL., Redefining the Corporation: Stakeholder Management And Organizational Wealth 12-16 (2002).

345 See, e.g., Millon, supra note 252 , at $1380-81$.

346 See, e.g., Marleen A. O'Connor, Restructuring the Corporation's Nexus of Contracts: Recognizing a Fiduciary Duty to Protect Displaced Workers, 69 N.C. L. REV. 1189, 1235-46 (1991) (explaining how the contractarian rationale can be used to protect workers' implicit relational contracts in the corporation).

347 See Blair \& Stout, supra note 1, at 253-54; GREENFIELD, supra note 72 , at 47 .

348 GREENFIELD, supra note 72 , at 29-33. 
have fiduciary obligations to multiple groups. ${ }^{349}$ The contrast between this model and the property theory is sharp in that this question is resolved by the property theory in favor of the corporation's residual voting interests. ${ }^{350}$

The contrast softens, however, along another dimension of potential conflict: the social versus private nature of the corporation. The nexus of contracts approach, perhaps counterintuitively, yields more readily to the "private" approach than does a property perspective. ${ }^{351}$ Indeed, the contractarian approach is implicitly, and sometimes explicitly, invoked in favor of that approach. ${ }^{352}$ A property view of the corporation in which the corporation is a proprietary creation of the state rather than a set of contracts lends itself at least as readily to the concession, or "social" theory. This potential amenability of property law as compared to contract law has been noted by the nascent literature on corporate law as property law. ${ }^{353}$

The idea that a property conception lends itself to a social view of the corporation is perhaps counterintuitive, but compelling. Yet the arguments typically deployed in favor of this view are unpersuasive. A typical approach begins with the observation that of course there are restrictions on how people use their property. The next, often implicit, step is that regulation of the use of property justifies intervention in corporate governance. That is, "[a]n adjustment in corporate governance is just that-a regulation of business." ${ }^{354}$ In a sense, this perspective echoes the historical origins of corporations, where

349 Millon, supra note 252, at 1388.

350 See supra Section III.B.

351 See Choi \& Min, supra note 108, at 11-12 (explaining that the nexus of contracts approach has led scholars to advocate for fewer mandatory terms and an emphasis on private ordering in corporate law).

352 See Stephen M. Bainbridge, Community and Statism: A Conservative Contractarian Critique of Progressive Corporate Law Scholarship, 82 CORNELL L. REV. 856, 903 (1997).

353 See Michael J. Whincop, Painting the Corporate Cathedral: The Protection of Entitlements in Corporate Law, 19 OXFORD J. LEGAL STUD. 19, 3335 (1999).

354 GREENFIELD, supra note 72 , at 45 . 
they were generally only available for businesses tinged with a public purpose. ${ }^{355}$

There is stronger argument, however, for why the property theory is at least as amenable as the contractarian theory to a social conception of the corporation. The idea of contracts having a social purpose is unwieldy. The role of courts in contract law is to interpret contracts and further contracting parties' intent. Those who are not even arguably a party to a corporate contract, such as the community, have no standing in a dispute over how to interpret it.

Property, on the other hand, as a right enabled by the state, can have such a purpose. Restrictions on the purposes for which owners may use their property are commonplace. While the government can impose obligations on the affirmative use of property, ${ }^{356}$ courts' role in private contracts is more limited. Although courts may refuse to enforce agreements that violate public policy, they usually do not rewrite those agreements to further public policy. In this sense, there is a template within property law for intervention into corporate affairs that is largely absent from contract law.

As another example, progressive corporate law theorists have tried to promote the idea of "reliance" as an interest that should be protected by corporate law. ${ }^{357}$ Although this may suggest that progressive corporate law is tied more to contract (as promises can be enforced as a result of reliance) than to property, it is important to note that property interests can also be created by reliance-as in the case of adverse possession. ${ }^{358}$ Thus, the property theory is not necessarily inconsistent with the reliance-based notions of stakeholder theory. Further work is necessary to hash out the relevance of property theory to stakeholder conceptions of the corporation.

Indeed, the tendency of the nexus of contracts theory to devolve into a shareholder/stakeholder debate has obscured the

355 See, e.g., David K. Millon, Theories of the Corporation, 1990 DUKE L.J. 201, 207 (1990) (explaining that corporations were originally usually chartered for businesses serving public functions).

356 An example is the law of nuisance. See JosepH A. JoYCE \& Howard

C. Joyce, Treatise on the LaW Governing Nuisances 6-9 (1906).

357 See, e.g., GREENFIELD, supra note 72, at 51-53.

358 Id. at 46. 
potentially rich implications of the property conception of corporate law. Overly simplistic debates about whether shareholders are "the owners," of the corporation rather than what ownership interests exist within the corporation have contributed to misunderstanding on both sides of the debate.

The property theory of the corporation does not dictate where the rights of stakeholders end up; it determines where they begin. That is, property owners can parcel out contractual rights to their property, which may recreate a "team production" approach, a stakeholder approach, or a shareholder primacy approach.

\section{CONCLUSION}

This Article seeks to establish a chain of individually modest assertions that together lead to new foundations for corporate law. The first assertion is that there are some ownership interests in the corporation-the corporation is not exclusively contractual but instead a mix of contract and property. ${ }^{359}$ Second, those ownership interests most plausibly belong to the owners of the residual control rights in the corporation-the voting shares, not necessarily to the holders of the residual economic rights of the corporation. Third, fiduciary duties follow primarily from those ownership interests, not contractual residual economic interests. Collectively, these assertions establish that there is a line to be drawn between contract and property, ascertained by the underlying theory of property, and that this dividing line identifies the boundaries of distinctively corporate law.

The property theory provides an explanation for many of the features of corporate law that are weakly supported by a purely contractarian perspective. It explains why corporate statutes deal almost exclusively with shareholders, why the corporation has so many in rem features, why a single law applies to the internal affairs of the corporation, and why it is sensible to talk about "internal" affairs at all. In practical

359 This point is well explicated in a recent article by George Mocsary, where he describes the corporation as a "triality" of property, contract, and associational rights. George A. Mocsary, Freedom of Corporate Purpose, 2016 BYU L. REV. 1319, 1328-42 (2016). 
terms, the property theory explanation helps to resolve otherwise difficult cases of loyalty in corporations with increasingly complex capital structures. Finally, the property theory provides some traction on the question of the social purposes of the corporation. 